Illinois State University

ISU ReD: Research and eData

Theses and Dissertations

3-19-2018

\title{
The Association Between Parental Beliefs About Sport Specialization And Athlete Sport Specialization Classification
}

Henry Mercier

Illinois State University, hmercie@ilstu.edu

Follow this and additional works at: https://ir.library.illinoisstate.edu/etd

Part of the Kinesiology Commons

\section{Recommended Citation}

Mercier, Henry, "The Association Between Parental Beliefs About Sport Specialization And Athlete Sport Specialization Classification" (2018). Theses and Dissertations. 875.

https://ir.library.illinoisstate.edu/etd/875

This Thesis is brought to you for free and open access by ISU ReD: Research and eData. It has been accepted for inclusion in Theses and Dissertations by an authorized administrator of ISU ReD: Research and eData. For more information, please contact ISUReD@ilstu.edu. 


\section{THE ASSOCIATION BETWEEN PARENTAL BELIEFS ABOUT SPORT \\ SPECIALIZATION AND ATHLETE SPORT \\ SPECIALIZATION CLASSIFICATION}

\section{HENRY J. MERCIER}

\section{Pages}

Context: Previous research has demonstrated a high prevalence of extrinsic pressures among single sport athletes. The influence of parental beliefs on a high school student athlete's decision to participate in a single sport rather than multiple sports has yet to be determined. Objective: To estimate a student athlete's level of sport specialization from parental sport specialization beliefs and to investigate independent relationships of potential factors influencing the decision to pursue a single sport. Design: Cross-sectional survey. Setting: High school athletics.

Participants: Fifty-seven high school student athletes (25 females, 32 males; mean age 15.6 \pm 1.6 years) selected onto freshmen, junior varsity, or varsity teams of soccer, volleyball, or basketball and their parents (34 females, 23 males; mean age 46.9 \pm 5.2 years) of two large (mean enrollment 1,805 students) public suburban schools. Intervention: Modified versions of two surveys previously used in sport specialization research were distributed to student athletes and parents at the beginning of each sport's season. Results: Regression analyses demonstrated that student athlete sports specialization was not associated with parents' beliefs about specialization (level of agreement in sustaining an overuse injury: $\chi^{2}=0.68, \mathrm{df}=2, \mathrm{p}=0.71$ and whether early sports specialization is a problem: $\chi^{2}=5.51, \mathrm{df}=2, \mathrm{p}=0.06$. When a parent responded that early sport specialization was "a problem", the odds of a student athlete being classified as highly 
specialized was 3.22 times higher than if a parent responded that early sport specialization was "not a problem". Further, when a parent responded that they "agreed" with participating in one organized sport year-round increases their child's likelihood of sustaining an overuse injury, the odds of a student athlete being classified as highly specialized was 1.51 higher than if the parent responded they had "no opinion" on the matter. However, neither of these odds ratios were statistically significant. Significant non-parametric correlations were found between sport specialization and the following parent perceived influential factors in an athlete's decision to pursue a single sport: need to stay competitive with other children $\left(\mathrm{r}_{\mathrm{s}}=0.636, p=0.01\right)$, better chance to receive a scholarship/contract $\left(\mathrm{r}_{\mathrm{s}}=0.501, p=0.01\right)$. Conclusion: The analysis of the data did not support the hypothesis that parental beliefs were associated with student athlete sport specialization. As an athlete's specialization level increases, parents perceived that staying competitive with other children and a better chance to receive a scholarship/contract as more influential in an athlete's decision to pursue a single sport.

KEYWORDS: Sport; Parent; Specialization 
THE ASSOCIATION BETWEEN PARENTAL BELIEFS ABOUT SPORT

SPECIALIZATION AND ATHLETE SPORT

SPECIALIZATION CLASSIFICATION

HENRY J. MERCIER

A Thesis Submitted in Partial

Fulfillment of the Requirements

for the Degree of

MASTER OF SCIENCE

School of Kinesiology and Recreation

ILLINOIS STATE UNIVERSITY

2018 
Copyright 2018 Henry J. Mercier 
THE ASSOCIATION BETWEEN PARENTAL BELIEFS ABOUT SPORT

SPECIALIZATION AND ATHLETE SPORT

SPECIALIZATION CLASSIFICATION

HENRY J. MERCIER

COMMITTEE MEMBERS:

Noelle Selkow, Chair

Kelly Laurson 


\section{ACKNOWLEDGMENTS}

I would first like to thank my primary thesis advisor Dr. Noelle Selkow, Director of Graduate Athletic Training Education at Illinois State University. Her door was always open whenever I needed guidance in writing this thesis and looking into the future beyond graduate school. Her astute and tenacious character challenged me never to cease asking questions and to never be complacent with the knowledge I possess. Secondly, I'd like to thank Dr. Laurson, an associate professor at Illinois State University. He was always able to facilitate my thinking process without giving me the answer and constantly had fun while doing it.

Thirdly, I'd like to thank the Unit 5 District of McLean County, the high school coaches, and athletic directors who supported my project. Finally, I must express my gratitude to my family and friends for providing me with support and continuous inspiration throughout my years of study, the process of researching, and writing this thesis. This accomplishment would not have been possible without them. Thank you.

H.J.M. 


\section{CONTENTS}

Page

ACKNOWLEDGMENTS

TABLES

CHAPTER I: INTRODUCTION 1

CHAPTER II: LITERATURE REVIEW 4

$\begin{array}{ll}\text { Evolution of Sports } & 5\end{array}$

$\begin{array}{ll}\text { Sports and the Media } & 8\end{array}$

$\begin{array}{ll}\text { Sports Participation } & 9\end{array}$

Constraints to Sports Participation $\quad 9$

Factors Influencing Sports Participation $\quad 12$

High School Athletic Injury Epidemiology 15

$\begin{array}{ll}\text { Sport Specialization } & 19\end{array}$

The Definition and Roots of Sport Specialization 19

$\begin{array}{ll}\text { The Encouragement of Sports Specialization } & 21\end{array}$

The Benefits of Sports Specialization $\quad 22$

The Risks of Sports Specialization $\quad 23$

$\begin{array}{ll}\text { Overtraining } & 23\end{array}$

Injury Risk and Underlying Contributions 25

$\begin{array}{ll}\text { Recommendations } & 30\end{array}$

$\begin{array}{ll}\text { Conclusion } & 30\end{array}$

CHAPTER III: METHODS

$\begin{array}{ll}\text { Study Design } & 32\end{array}$ 
Participants

Procedures

Instrumentation

Statistical Analyses

Data Reduction

CHAPTER IV: RESULTS

CHAPTER V: DISCUSSION

Limitations

CHAPTER VI: CONCLUSION

REFERENCES

APPENDIX A: ADDITIONAL RESULTS

APPENDIX B: PARENT SURVEY 


\section{TABLES}

$\begin{array}{lll}\text { Tables } & \text { Page }\end{array}$

1. Descriptive Statistics: High School Student Body Demographics 33

2. Descriptive Statistics: Student-Athlete Characteristics 33

3. Descriptive Statistics: Parent Age 34

4. Descriptive Statistics: Parent Characteristics 34 


\section{CHAPTER I: INTRODUCTION}

Sport specialization is defined as intense training in one sport year-round at the exclusion of others. ${ }^{1,2}$ Multiple position, consensus, and re-affirmation statements express concerns about early sport specialization in youths and adolescents citing negative consequences such as overuse injury, overtraining, and burnout. ${ }^{3-7}$ However, evidence-based recommendations about sport specialization appeared to be backed by limited quality and inconsistent evidence ${ }^{2,3}$ until recently.

Data suggesting that sport specialization training is an independent risk factor for athletic injury did not emerge until 2015 when researchers demonstrated that the risk of sustaining an injury among single sport specialized athletes was 1.27 times greater than their counterparts after controlling for age and sport activity hours per week. ${ }^{8}$ Further, the risk of sustaining a serious overuse injury in this cohort was also greater (Odds Ratio [OR], 1.36). ${ }^{8}$ This report established the 3-point classification method for categorizing athletes as low, moderate, or highly specialized with the underlying premise being that sport specialization runs on more of a continuum and is less of a black and white image. ${ }^{8}$ Since this report, evidence has quantified the injury risk of highly specialized athletes. This cohort was 1.59 times more likely to report a previous history of any kind of injury and 1.45 times more likely to report an overuse injury. ${ }^{9}$ Longitudinal evidence also states that high sport specialization is associated with an increased risk of lower extremity injury (Hazard Ratio [HR], 1.85). ${ }^{10}$ Furthermore, training volume is a factor for increased injury risk of specialized athletes. ${ }^{9,11}$ For example, participating in a single sport for more than 8 months out of the year increases risk of sustaining an overuse injury. ${ }^{9,11}$ Other factors that have proven to be associated with reporting previous injuries related to sport specialization, specifically in the lower extremity are the following: participation in high competition volume 
( $>60$ competitions within a year) and participation on a club team. ${ }^{12}$ When applying sex to the equation, females were more likely to participate in high competition volume, participate on a club team, and be classified as highly specialized. ${ }^{12}$ Although all of these studies are crosssectional with the exception of McGuine et al. ${ }^{10}$ and thus are unable to establish a cause and effect relationship, they consistently re-affirm the original statement by Jayanthi et al. ${ }^{8}$ that highly specialized athletes have an increased risk of injury compared to low specialized athletes.

Clearly, evidence regarding the consequences of sport specialization as it relates to injury and its associated aspects have been quantified. However, investigations examining the influences leading an athlete to specialize have only begun to reach the surface. Padaki et al. ${ }^{13}$ identified two external pressures that are prevalent among specialized athletes: parents and coaches. Specialized athletes were more likely to report being told to not participate in other sports by their coaches and parents. ${ }^{13}$ Additionally, parents of specialized athletes report directly and indirectly (i.e. paying for personal training) influencing their child to specialize with the expectation that they would play at the collegiate or professional level. ${ }^{14}$ The reality of these parents' expectations are misguided. The sport with the highest percentage of high school athletes that participate at the collegiate level is lacrosse for males at $12.3 \%$ and females at $24.1 \%{ }^{15}$ Additionally, the sport with the highest percentage of college athletes that turn professional based on the number of draft picks made in various leagues (i.e. NFL, NBA, WNBA, MLB, NHL, MLS) is baseball with $9.1 \%$ and the sport with the lowest is women's basketball with $0.9 \% .{ }^{16}$ If parents exert a high level of influence on their child to specialize in one sport, then it's possible that they don't agree with or know the risks of specializing in a single sport. One could then speculate that if parents don't believe sport specialization is a problem or don't see it as a risk factor for injury, then this could play a role in a child's level of 
sport specialization. Further, a parent's perception of why their student-athlete decided to pursue a single sport rather than play multiple sports has yet to be determined and may bring more insight into the motivations behind playing a single sport. Therefore, the purpose of this study is to determine the association between sport specialization classification and parental sport specialization beliefs. The secondary purpose is to examine independent associations between factors perceived by parents as influential in determining a student athlete's decision to pursue a single sport and athlete sport specialization classification. 


\section{CHAPTER II: LITERATURE REVIEW}

During adolescent years, many either have or still are identifying and exploring physical activities in the hopes of finding something they like to do. Sports is a vast area worth exploring due to the array of opportunities provided for all individuals. The objective of sports is to develop a team or individual through the practice of skill, conditioning, and mental training and express these characteristics by playing against another team or individual. Theoretically, then, the more an individual commits and dedicates time to the nuances of their sport(s), whether it be team or individually based, the more they would excel in their craft thereby leading to future success. The idea of sports specialization is built on this primary basis. However, much debate remains about what constitutes sports specialization, the role of parental involvement, the characterization of athletes and parents, as well as the advantages and disadvantages of overwhelming participation in one sport. Therefore, the purpose of this study is to compare the prevalence of high school athletes across multiple team sports in a suburban community, examine the characteristics of athletes who specialize in one sport and their parental connection, while investigating potential relationships to injury. The aim of this review is to paint the picture of sports specialization beginning with a description of the sports system and its development in the United States through cultural and economic lenses, as well as capture the amount of youth and adolescent sports participation and the factors that influence such involvement. Injury epidemiology and risk factors among high school adolescents will be discussed including the risks and benefits of playing sports in general and then specifically in regards to sports specialization. 


\section{Evolution of Sports}

Youth sports became a massive trend 70-80 years ago starting with the development of little league baseball in 1939 in Williamsburg, PA. ${ }^{19}$ Until Title IX was passed in 1972, most opportunities to play sports were for males. ${ }^{19}$ According to the National Federation of State High School Associations, female sport participants grew from 294,015 in the 1971-1972 school year to an astonishing 1,300,169 in the $1973-74$ school year-a $442 \%$ increase. ${ }^{47}$ Around the same time Title IX was passed, there appeared to be a cultural shift in the American family household. According to a U.S. Bureau of Labor statistics article from 2007 adapted from the Current Population Survey (CPS) that surveys 60,000 households monthly, labor force participation rates of women with children under the age of 18 increased from $45 \%$ to $55 \%$ between 1970 and $1980 .{ }^{43}$ In 1996, that amount rose to an all-time high of $70 \%$ before gradually dipping down. ${ }^{43}$ Thus, as more women pursued careers outside of the home, there needed to be an outlet that would keep their children occupied until either parent was done work for the day. This, along with other factors such as keeping children away from illicit activities, attracted parents to involve their children in sports. ${ }^{19}$ Sports are considered a safe haven for youth and adolescents because they were and continue to be organized and adult-supervised. Moreover, with juvenile (10-17 years old) violent crime index arrests gradually declining to an all-time low in $2014,{ }^{36}$ it's possible that sports may have and continue to play a role in this statistic.

In addition to the reasons for sports being attractive due to the aforementioned events, the industrialization of America also increased sports' vitality through promotion and business. The technological advances that improved communication, transportation, and production helped the growth of our resource supply. Additionally, new jobs in the manufacturing industry proved attractive for many thereby drawing them into the city and out of rural areas that were dominated 
by agriculture. Instead of working in small shops or farms, numerous individuals were working for big companies. One of the primary effects of the late industrial revolution was the change in work time. Between 1900 and 1950, the average number of weekly hours for all workers dropped from 60 in 1900 to 40 in 1950 and went as low as 35 in $1975 .{ }^{31}$ The roots of this decline has been hypothesized to stem from technological advances as well as change in wage distribution. ${ }^{31}$ Currently, adults between the ages of 35 and 44 years old spend about 4.1 hours a day performing leisure activities such as watching television, socializing, participating in sports or exercise, reading, or relaxing. ${ }^{32}$ Those between ages 15 and 19 years old spend the most time in sports, exercise, and recreation than any other age group. Not surprisingly, watching television accounted for more than half of the time spent on leisure activity. ${ }^{32}$ Increased leisure time could allow for more time spent on other extracurricular activities. Extracurricular activities can mainly be described as after-school activities. However, in the 1930s, non-school programs such as the YMCA and other national organizations began to take control of competitive youth sport from public school programs. These organizations created athletic opportunities for individuals of various skills that school programs could not. ${ }^{18}$

Currently, there is still a divide between non-school and school sports programs in the United State since the American government system leaves any unattended responsibilities up to the states. ${ }^{17}$ In other words, 50 states may have 50 different policies about the same responsibility. Funding sports is one of those responsibilities. If the state takes no action to support sports participation, local authorities are next in line. Given that the formulation and advertisement of sports participation is left up to local authorities, sport is effectively a "free market". ${ }^{17}$ 
There are two types of sports programs that make up this free market of youth sports in the United States: community-based programs and school-based programs. ${ }^{18}$ Community-based programs are largely dependent on fundraising events, non-profit organizations, commercial sport or fitness clubs, community organization, or agency-sponsored units as sources of funding. ${ }^{18,19}$ Categories of youth sports programs include agency-sponsored programs, national youth service organizations, club sports, and recreational programs. In contrast, school-based programs include intramural and interscholastic programs. ${ }^{42}$ These programs are supported in three predominant ways: commercialization via corporate sponsorship, booster clubs, and participation, or "pay to play", fees. ${ }^{21,22}$ These sources of funding have largely been the product of American economics, the passage of Title IX, and the industrialization of America, which has contributed to an uprising of sports promotion through media.

Secondary schools receive funding primarily from local and state sources as opposed to federal sources. ${ }^{25}$ For example, about $91 \%$ of funding came from state and local sources for K-12 education in $2013 .{ }^{29}$ When a recession undermines the American economy as in 1980 or 2008 , states will cut spending to many programs in order to balance the fall in revenue that is a result from decrease in consumer expenditure. Because state and local authorities are the chief funding sources for elementary-secondary schools, spending on education will shrink. While this impacts many school's educational activities, sports are most susceptible to cuts because they're considered extracurricular activities. ${ }^{20}$ When cuts need to be made, schools are challenged to not only give equal sport opportunities for both genders, it also requires them to have equal spending due to Title IX. These factors put strain on the athletic budget in many schools creating a scenario where $82 \%$ of schools experience athletic budget pressures according to a national voice for interscholastic athletic administrators (NIAAA) Survey. ${ }^{38}$ Due to tight budget requirements, 
school programs will turn to other methods such as corporate sponsorships, pay to play fees, booster clubs, and fundraising to support the continuation of these programs.

\section{Sports and the Media}

Relationships between big businesses and companies trace back to the introduction of the television. The television has been a source of information and entertainment, such as sports, for almost a century. According to the US Census Bureau, 9\% of households owned a television in 1950. This number sharply rose to $63 \%$ within 5 years and $98 \%$ in $1980 .{ }^{43}$ Further, a few years after the establishment of Entertainment and Sports Programming (ESPN) in 1979 it had reached 4 million homes. By 1986, this number had grown to 37 million. ${ }^{33}$ This allowed many Americans to view their favorite sports and players indirectly instead of attending the actual game.

Sports media serves several purposes for its viewers including: the ecstasy of anticipation leading up to a major sporting event, information on impactful players, history, statistics, and matchups, stories from players, coaches, and teams in the hopes of facilitating an emotional attachment, and an overall outlet for individuals to escape daily life. ${ }^{19}$ However, encircling the sports media world is the business supremacy. Notably, professional sports team organizations such as the Major League Baseball (MLB) or the National Football League (NFL) make money from media. For example, in the 1960s through 1980, the MLB earned $\$ 80$ million from local and network electronic media. ${ }^{34}$ By 1990 , however, the MLB had earned $\$ 612$ million. The NFL had a similar trend from $\$ 167$ million in 1980 to $\$ 948$ million in $1990 .{ }^{34}$ This substantial growth in income can likely be attributed to increase in interest in professional sports, the number of individuals having access to television, and the amount of subscribers to sports channels. ${ }^{34}$ 
The number of individuals having access to television for entertainment, whether its sports or other entertainment shows, invites businesses to advertise their merchandise. In addition, businesses can form their commercials to target a specific audience and enhance their image. Sponsorship also plays a major role in advertisement. A sponsorship takes place when a company or business builds a relationship with an entity that promotes that company's image commercially in exchange for funds, resources, or services. ${ }^{38}$ According to the international events group (IEG), in 2015 , the sports industry accounts for $69 \%$ of the $\$ 20.6$ billion sponsorship market in North America. ${ }^{41}$ In high school athletics, corporate sponsorship is the second most common sought after form of revenue generation for a school's athletic budget after fundraising and participation fees. Fifty-seven percent $(n=360)$ of high schools who responded to a National Survey indicated that they generated revenue from sponsorships. ${ }^{40}$ Although this does not cover the entire cost of athletics within a high school, it covers a large portion of equipment and supplies as well as maintenance and renovation costs. ${ }^{40}$

\section{Sports Participation}

\section{Constraints to Sports Participation}

Two major constraints are involved in high school sports programs that may contribute to decreased high school sport participation: cost and roster size. ${ }^{18}$ Inherently, not every studentathlete who wishes to play a sport in school will be accepted on the varsity or junior varsity team. Due to this, those who do not make the schools teams will likely turn to local and national organizations to participate. ${ }^{18}$ Those of affluence who are able to afford private sport programming from community-based programs will likely have more access to a variety of options. ${ }^{26}$ Costs, however, do not escape athletes who play school sports. About $27 \%$ of respondents to the 2013 Sports and Fitness Industry Association (SFIA) participation topline 
survey reported paying two-hundred dollars or more for their child(ren) to play sports in school. ${ }^{30}$ In addition, about 57\% report an increase in their child's sports fee compared to the previous school year. ${ }^{30}$ These are flat rate fees that allow children to participate in the school sport. However, it's important to note that these does not include fees for equipment and other additional sports fees. In fact, the average cost of for a child's participation in a school sport when one includes participation fees, equipment, uniforms, and additional team fees is $\$ 381 .{ }^{27}$ Given the uprising in cost to play school sports, socioeconomic status is an unquestionable factor that plays a role in sports participation. About 1 in 5 lower income parents, earning less than $\$ 60,000$ a year, reported a decrease in their child's sports participation. ${ }^{27}$ Conversely, other evidence shows that sports participation rates are similar in schools who do and don't have sport participation fees even when accounting for socioeconomic status ${ }^{28}$. In a cross-sectional analysis of sports participation, participation fees did not appear to affect sport opportunities. However, when accounting for level of poverty at schools based on the amount of students eligible for free lunch, schools considered to be on the low poverty scale were more likely to have sports participation fees than those on the high-poverty scale ${ }^{28}$ While this study provides an informative insight into how these fees affect sports participation based on some demographic variables, their sample only represents Michigan's public schools. Further studies would need to examine similar relationships in other state schools to establish consistency across multiple samples.

Even though pay to play participation fees appear to be on the rise, club organization fees present a steeper issue. Although statistical data reporting for club organizations is scant because of the vast number of clubs for multiple sports and therefore difficulty of data collection, news reports still convey the tip of the iceberg in the terms of cost. For example, a 2011 CBS news 
report $^{24}$ interviewed the parents of a son who plays travel baseball and a dad who has three girls playing club volleyball. The parents of the son estimate that they pay $\$ 4,000$ for baseball, $\$ 1,500$ in team fees alone and the rest includes travel expenses, equipment, and park fees. ${ }^{24}$ The volleyball family estimates that they pay $\$ 8,000-\$ 10,000$ total per year to play volleyball, with $\$ 1,500-\$ 2,000$ attributed club team fees. ${ }^{24}$ The Dallas Morning News described a family who spent nearly $\$ 15,000-\$ 20,000$ to play select softball. ${ }^{23}$ The report goes on to quote various coaches who explain that they recruit through club events, which may appear sensible for college coaches as high school seasons likely collide with their own seasons. ${ }^{23}$ In the latter article, the payoff was the scholarship the softball athlete received to go to a top college. According to the College Board, since 1981-1982 the average price tag of tuition, room and board for a 4-year public college has increased significantly from about $\$ 7,500$ to just over $\$ 20,000$ in $2016 .{ }^{44}$ For a private 4-year college, this average cost is more than double. ${ }^{44}$ Consequently, it would be practical to view athletic scholarships as an attractive route for many families due to the upsurge in college costs. Yet, despite this seemingly appealing path many high school athletes do not end up playing in college. According to the NCAA, the highest percentage of high school athletes that went on to compete at the collegiate level was $11.9 \%$ in men's lacrosse while the lowest was $2.6 \%$ in men's wrestling. ${ }^{45}$ For women, the highest percentage of high school athletes that went on to compete at the collegiate level was $23.4 \%$ in women's ice hockey while the lowest was $3.8 \%$ in women's basketball. ${ }^{45}$ Further, the chances of a high school athlete receiving a scholarship is 55:1. ${ }^{46}$ If adjusting for gender, females have better odds (47:1) at receiving a scholarship than males $(63: 1) .{ }^{46}$ It's important to note that these statistics only represent "full" scholarships. ${ }^{46}$ While the odds are dependent on the sport played, gender, and number of 
scholarships available, it's unlikely that a high school athlete will receive an athletic scholarship to participate in sports at the collegiate level.

\section{Factors Influencing Sports Participation}

The underlying roots of the growth in sports may stem from social and cultural shifts in parenting, families, and childhood experiences. For example, since the 1950s there has been an increase in both parents pursuing careers outside of home or single parents working to support their families. ${ }^{48}$ Organized sports after school occupy a child's time until their parent can leave work to pick them up. Additionally, those parents would know that their child is in a safe and productive environment as opposed to involving themselves in other mischievous or illicit activities. Parents may therefore see sports as a way to spend quality time with their kids, especially now that the trend for both parents to pursue careers is increasing as opposed to one parent staying home. Parents may also see sports as an avenue for success, which could boost their morale in the context of parenting adequacy. ${ }^{48}$

Sociodemographic characteristics may play a role in an athlete's development and level of participation. One prospective cluster study investigated patterns of participation in sports and other organized activities in order to shed light on how youth development varies with different combinations of activities. ${ }^{49}$ Not surprisingly, youth within the sports cluster, defined as "high participation in sports and low participation in other activities" or sports plus cluster, defined as "generally high participation in all activities including sports", were more likely to be part of a family with parents who received college education or higher and grossed a higher annual income compared to other activity groups (i.e. school or religious groups). ${ }^{49}$ Another overarching key point was the discovery that youths involved in sports plus other activities was most 
associated with positive youth development outcomes such as social connectedness to school, peers, confidence, academic competence, and positive character. ${ }^{49}$

Even though youth development may describe the positive impact of sports and other activities, it still may not fully explain why youths continue to play sports. The answer may lie in intrinsic and social factors. Research has consistently shown that intrinsic and social factors such as developing mastery of a skill or being with friends appear to outrank extrinsic factors such as winning or receiving awards in creating fun in sport for youth. ${ }^{50,51}$ One study predicting motivational outcomes in youth soccer players by their relationships with peers and parents suggested that the combination of peer, parent, and friend quality of relationships and levels of acceptance was critical to sport enjoyment, lower stress, and self-motivation. ${ }^{52}$ However, it seems that this intrinsic thinking may depend on the age of the athlete as it tends to shift towards more achievement outcome-based factors as one enters into adolescence. ${ }^{53}$

Another potential answer to why sport garners many participants is parental involvement. Parents are the first way children are introduced to athletics since they have the resources to make this happen. This initial exposure may be referred to as the "sampling years". ${ }^{55}$ Parents then continue to be the keystone of youth development by instilling their values onto their sons and daughters while fostering sport satisfaction and meaning through encouragement and praise as presented in the following studies. ${ }^{57-59}$ In a cross-sectional study examining adolescent sport value acceptance and the role of parental involvement within the context of that acceptance, researchers concluded that the most important values to athletes were of the competence and moral type as opposed to status values such as leadership and winning. ${ }^{57}$ This is in part due to the athlete's perception that their parent's paid more attention to their moral and competence values. Additionally, the adoption of parental sport values by their respective adolescents was more 
predictable if the athlete felt that their parent(s) were understanding towards their sport and exerted praise as opposed to pressure. ${ }^{56}$ Thus, it would seem that the influence of parents is profound through the interactions they have with their adolescent athlete. Other evidence also suggests that it's the parent's support through encouragement that exerts the greatest influence on an athlete's enjoyment and importance of their sport. ${ }^{57}$

In regards to the pressure felt by parents, the literature shows that pressure appears to have a negative consequence on sport involvement. ${ }^{58,59}$ For example, a systematic review included 43 empirically based studies that assessed dropout or the intention to dropout of sports in 5-19 year-old individuals. ${ }^{58}$ The authors used the leisure constraint theory to allow for the synthesizing of their results into three categories: intrapersonal constraints defined as "internal states and attributes that are important in forming the desire to participate in or have a preference for a particular activity", interpersonal constraints defined as "social factors that affect leisure preferences resulting from interactions with others", and structural constraints defined as "external factors that interfere or disrupt the connection between preferences and participation" ${ }^{58}$ Results showed that the most frequent intrapersonal constraints identified as reasons for dropping out of sport were lack of enjoyment and low perception of physical competence. The most frequently cited interpersonal constraint was 'pressure' from others such as coaches, peers, and parents. The top most identified structural constraints were time and injury. ${ }^{58}$

Moreover, the degree of pressure may be perceived differently from the child than the parent. One study compared 9-11-year-old children and parental perceptions of parental support and pressure and how these perceptions influenced enjoyment in hockey ${ }^{59}$ They also examined the differences and similarities of agreement level in parental involvement in the child's sport, 
enjoyment of the sport, and the child's skill. The researchers showed children and parents disagreed with how much pressure was received by the child with children reporting significantly higher scores on measures of pressure from their father $(p=0.001)$ and mother $(p=$ $<0.001)$ compared to the parents. ${ }^{59}$ It's also interesting to note that parental pressure specifically from the father, not the mother, was negatively associated with the child's general feelings about the sport. However, support from either parent was not associated with the child's general feelings about hockey. ${ }^{59}$ From regression analyses, a father's perception of their child's skill was predictive of a child's perception of skill. ${ }^{59}$ The father-child agreement about parental pressure was also predictive in the child's general feelings about hockey. ${ }^{59}$ This evidence displays the profound role that fathers play in their child's sport life. One explanation proposed by the authors for this could be that the sports atmosphere is where fathers tend to show dominance because it expresses their masculinity and it gives them a chance to bond with their child outside of the house. ${ }^{59}$

Overall, the previous evidence suggests sports play a role in positive youth development by promoting social connectedness, increasing confidence and character, as well as boosting selfesteem. Further evidence, as previously stated, reveals that parents have an immense role in how youth feel about the sports they play and the values that they embrace. These values could affect the characteristics of the sports adolescents play such as the type, the volume, and the level. Therefore, the importance of parental involvement in sports cannot be underestimated.

\section{High School Athletic Injury Epidemiology}

It has been clearly demonstrated that youth sports participation has increased over the past few decades and potential reasons for this growth were discussed in relation to the overall aim of this review. Theoretically, an increase of sports participation results in an upsurge of 
injury incidence since more individuals are being exposed to potentially injurious environments. In the 2014-2015 High School sport-related injury survey, for every 1,000 athlete exposures 2.13 injuries would occur. ${ }^{60}$ Unfortunately, injuries may result in time loss and long-term costs. As a result, sports injuries have received much attention in the literature in the attempt to describe these consequences for the athlete, present the level of economic burden sports injuries put on athletes and their families, and promote injury prevention strategies to alleviate these consequences. These injury prevention strategies are the result of a 4-step process defined by Van Mechelen et $\mathrm{al}^{61} .: 1$. Establish the extent of the sports injury problem through epidemiological studies, 2. Mechanisms and factors that play a role in sports injuries must be identified, 3. Commence with injury preventative efforts to moderate these factors, and 4. Assess the effectiveness of the injury prevention strategies by collecting further injury epidemiological data to show differences before and after the intervention. ${ }^{61}$ The concerns with this approach are many. First, epidemiological studies of sports injuries may not use a consistent definition of "injury" and the methods of these studies may also not represent the target population. Therefore, the results of the studies may vary and be difficult to compare. ${ }^{62}$ Second, identifying risk factors imply linear relationships to the outcome variable and may disregard other variables that may introduce an interaction. Third, injury prevention strategies may only target one variable in the web of many that contribute to injury. With the latter two concerns, it may prove problematic to discern the magnitude of contribution that each variable has in the incidence of sports injury. ${ }^{62,63}$

However, before the aforementioned concerns were voiced, the documentation of high school athletic injuries has been demonstrated since the turn of the $21^{\text {st }}$ century. For example, in 2006 the CDC reported that high school athletic injuries account for approximately 2 million injuries annually. ${ }^{64}$ Additionally, the estimated healthcare cost of high school sports injuries 
sustained by varsity athletes in North Carolina was reported to be $\$ 13.7$ million and about $\$ 2733$ per athlete. ${ }^{65}$ While this sample does not account for all levels of high school athletes nor is nationally representative of all US varsity athletes, it gives a snapshot of the direct financial burden that sports injuries may have on families.

Since the 2006 CDC report of annual athletic injuries, many epidemiologic studies were performed to demonstrate the injury rate and characteristics of injuries in high school athletes. ${ }^{66-}$ ${ }^{69}$ For example, the rate of severe injury, defined as any injury that resulted in the loss of more than 21 days of sports participation, in high school athletics was 0.39 per 1,000 athletic exposures (AEs). ${ }^{66}$ Among sex comparable sports, females had a higher injury rate compared to their male counterparts $(0.29 / 1,000$ AEs vs $0.23 / 1,000$ AEs $) .{ }^{66}$ Not surprisingly, the severe injury rate was higher in competition (0.79) than in practice (0.24). ${ }^{66}$ Additionally, the most severe injured body part was the knee followed by the ankle. ${ }^{66}$ This was also true in another epidemiological study examining injury rates between practices and competition where the injury rate in competition was higher $(4.63 / 1,000 \mathrm{AEs})$ compared to practice $(1.69 / 1,000 \mathrm{AEs}){ }^{67}$ In sex-comparable sports, females had a higher rate of injury in competition than their male counterparts. The body region commonly injured was the lower extremity, specifically the ankle $(22.7 \%, n=324,969) .{ }^{67}$ To add to this body of evidence, the rate of injuries requiring surgery was reported to be 1.45/10,000 AEs. ${ }^{68}$ Again, among sex-comparable sports, females had a higher risk of needing surgery (1.24) than their male counterparts $(0.94) .{ }^{68}$ Further, the rate of injuries was higher in competition (3.23) than in practice $(0.79) .{ }^{68}$

Breaking down injuries by mechanism may prove useful in understanding their prevalence. For example, the rate of overuse injury among high school athletes reported by an epidemiological study comparing overuse injuries in collegiate and high school athletes using the 
NCAA injury surveillance system and the high school reporting information online database was found to be 1.64 per 10,000 athlete exposures ( $n=3168$ injuries) during the period of 2006-2007 to $2012-2013 .{ }^{69}$ In high school athletes, the top 3 body parts most likely to sustain overuse injuries are the lower leg, knee, and the foot/ankle. ${ }^{69}$ These 3 body parts accounted for over half the overuse injuries reported for high school athletes in this study. Across sex-comparable sports in high school, females always had a higher rate of overuse injury ${ }^{69}$ The two most common diagnoses of overuse injuries in high school athletes were muscle/tendon strain $(33 \%, n=3165)$ and tendinitis $(25 \%, n=3165)$ though a muscle/tendon strain is generally thought to be an acute injury. ${ }^{69}$ This was also true in college athletes $(19 \%, 23 \% n=3554$ respectively), but at a reduced level. ${ }^{69}$ This could be due in part by the increased severity of injury in college athletes as shown by the $20.4 \%(n=3554)$ of collegiate athletes who took longer than 21 days to return to play compared to $7.7 \%(n=3165)$ of high school athletes. ${ }^{69}$ Moreover, it's been documented that skeletal maturity is still occurring in high school athletes when these injuries occur. ${ }^{70-72}$

Given the results of these epidemiological studies it's apparent that the lower extremity sustains more injuries than other body segments, being female may increase one's risk of injury, and playing in a organized sport competition may also increase one's risk of injury. The latter two conclusions could be identified as examples of risk factors for future research among sports injuries. This brings us to our next step within the 4-step approach described by Mechelen et al. ${ }^{61}$ Risk factors can be divided into two categories: intrinsic and extrinsic. ${ }^{62}$ Extrinsic risk factors are environment-dependent and can include examples such as rules and regulations, weather, gender, and playing surface. ${ }^{62}$ These factors do not tend to be modifiable and are thus not attractive to study. Intrinsic risk factors, however, are athlete-dependent and can be modifiable or nonmodifiable.$^{62}$ This category can include examples such as previous injury, biomechanics, muscle 
strength, muscle flexibility, and fitness level. ${ }^{73,74}$ Risk factors may be specific for certain injuries to body segments. For example, specific anthropometric, neuromuscular, and biomechanical risk factors such as $\mathrm{BMI}^{75}$, knee valgus $^{76}$ and internal rotation positioning ${ }^{77}$, decreased gluteus medius strength ${ }^{78}$, and low knee separation distance during a drop jump task ${ }^{79}$ have been identified to be risk factors for knee injuries.

Although it is impossible to effectively prevent all injuries in sport, reduction of injuries can be accomplished. Injuries represent a multifactorial event that can be a product of intrinsic and extrinsic factors. One such extrinsic factor that may contribute to athletic injuries is sports specialization.

\section{Sport Specialization}

\section{The Definition and Roots of Sport Specialization}

Sport specialization can be defined as "year-round intensive training in one sport at the exclusion of others". ${ }^{1}$ The goal of specializing in a field of study, much like doctors and surgeons, is to achieve excellence in a particular set of skills with the hopes of achieving an elite level status. ${ }^{1,80}$ Authors have remarked that using a continuum may be helpful in further defining sport specialization and identifying athletes at increased risk of injury ${ }^{8}$. The idea of sports specialization being put on a continuum as opposed to a black and white picture through an observational study performed by Bell et al. ${ }^{12}$ The authors determined that multiple factors influenced an athlete's level of sports specialization. Included among these factors were classification methods: self-classified versus the 3-point scale proposed by Jayanthi et al. ${ }^{8}$ They found that athletes who self-classified themselves were more likely to be a "multi-sport" athlete as opposed to a "single-sport" athlete. Comparing the two classification methods revealed no significant associations thus lending support to the difficulty of classifying athletes into categories. For example, $8.6 \%(N=26)$ were 
self-classified as single sport, but were placed in the low specialization category. ${ }^{12}$ On the other hand, $24.2 \%(N=73)$ of athletes self-classified themselves as a multisport athlete, but were placed in the high specialization category based on the 3-point scale. ${ }^{12}$ Generally, logic would deem single sport athletes as the most likely to be high specialized, but it appears that the degree of specialization varies regardless of single sport or multisport classification.

In the context of sport specialization's cited definition ${ }^{1}$, there remains to be issues associated with its connotation and word choice. First, the definition appears to act as a black and white label of single sport athletes as opposed to a continuum that includes multisport athletes on the other end. Secondly, the definition does not quantify "intensive" or "year-round", which makes it difficult to categorize those who may specialize in one sport. Thirdly, the gross implication of the definition does not detail the type of playing an individual is involved in throughout the year (i.e structured vs. unstructured) and disregards the element of recovery in the context of athletic performance. How much training an athlete must participate in to count towards the "year-round" parameter and what that training has to consist of to be counted as "intensive training" (i.e. strength and conditioning vs. deliberate practice) remains to be seen. With a consensus yet to be reached about this definition, it may be difficult identify athletes who specialize.

Other authors present a different perspective on specialization that may influence the way we define it. In a qualitative study of talented athletes, Côté ${ }^{55}$ stated that specialization was 1 of 3 stages in athletic development. In this stage, an athlete chooses to solely focus on and commit to one sport while decreasing their time spent on other activities. ${ }^{55}$ Similarly, Bloom ${ }^{81}$ notes that in the second phase of athletic development, which encompasses the period of preparation for developing talent, the young individual begins to commit to an activity full-time. However 
neither of these perspectives appear as popularly cited as the investigation that led to the " 10,000 hour rule" - a rule emphasized in Malcolm Gladwell's book Outliers: The Story of Success (ref). This rule made its appearance into the world in 1993 when Ericsson et al. ${ }^{82}$ proposed a minimum volume of deliberate practice to attain expert status in a given field. The authors concluded from their study of elite musicians that 10,000 hours over 10 years of deliberate practice, is necessary to become an expert in a particular area ${ }^{82}$ While putting expertise on a more objective level appears pleasant and tangible, it's unrealistic to extrapolate this idea to other domains such as art or sports. In fact, this idea has since been debunked by recent research in $2014^{117}$ and $2016^{118}$ where researchers contended that deliberate practice, specifically related to sports, only explained $18 \%$ of sports performance. ${ }^{117}$ The authors speculated that other factors such as genetics and psychological traits must also play a role. ${ }^{17,118}$

\section{The Encouragement of Sports Specialization}

Encouragement of sports specialization can come in many forms such as hearing stories about professional athletes "starting young" or watching the fame and success of professional athletes through the television. ${ }^{83}$ In another example, parent's over-involvement in the youth's sport in the hope of driving their success may be influenced by parenting adequacy. ${ }^{48}$ Parents may be held to believe that their parenting is effective based on their child's success. Therefore, sport specialization may be highly encouraged by parents for their own satisfaction. ${ }^{48,84}$ It's also possible to speculate that identifying talent at a young age may push a parent or a young athlete to pursue a single sport. On the other hand, per the 10,000 hour rule, talent may try to be created by specializing in a single sport. The narrow vision of this logic, however, does not account for the role of genetics. 


\section{The Benefits of Sports Specialization}

Skill acquisition and the optimization of motor skills is observed to be a benefit in regards to sport specialization. ${ }^{87}$ As theory would dictate, the more practice you have with a skill, the more enhanced that pattern will become. Given that most athletes do not make it to the collegiate or even professional level ${ }^{1,29}$, it would seem prudent to begin deliberately practicing a sport early in order to attain a high level of skill.

Deliberate practice includes highly structured practice activities designed to improve an individual's current level of performance. ${ }^{82} \mathrm{~A}$ widely cited study showed that those who achieved a high level of performance were also the individuals who were exposed to their practice early and began deliberate practice early. ${ }^{82}$ The issue with this model in which the dominant theme is expert attainment is a result of large amounts of deliberate practice is that the subtle ways of how to achieve those hours goes unnoticed. For example, one cannot expect a child at the age of 8 to practice the same amount of time as a teenager at the age of 13 . From a developmental perspective, they would be in different places.

Other discussed benefits thought to be related to sport specialization may include the following: better coaching and skill instruction, improved time management, structured use of time, enjoyment of sports and talent development. ${ }^{83}$ Finally, the obvious benefit of sports specialization is simply being involved in physical activity. From a physiological perspective, the health benefits of physical activity have been well documented in adults ${ }^{88}$ and youth. ${ }^{89,90}$ 


\section{The Risks of Sports Specialization}

Overtraining. Hans Selye's theory of general adaptation syndrome ${ }^{91}$ is the root of how we train our bodies to become bigger, faster, and stronger. His experiment in rats revealed that when various agents are applied (i.e. excessive exercise, spinal shock, sublethal doses of drugs), their body's will defend themselves. In other words, when exposed to an external stressor, the subjects responded in a manner appropriate to bring their body back to homeostasis. ${ }^{91}$ Additionally, the rat's body prepared itself for another bout of stress specific to the one it received before. This defense mechanism is broken down into three stages: alarm, adaptation or resistance, and exhaustion. The alarm stage produced several changes in the body's organ size, connective tissue, muscular tone, temperature, and accumulation of transudate within 6-48 hours of the applied stressor. ${ }^{91}$ This systemic response enables the body to survive and remove the stressor as quickly as possible. The adaptation or resistance stage constitutes a large hormonal response in an effort to recover from the stress applied to the animal. Selye also discovered that if the external stressor applied to the body is too great either in frequency, duration, or intensity, the body will be unable to recover and exhaustion will occur. ${ }^{91}$ Training as it relates to sports can be considered an external stressor on the body. The body adapts to a stressor and builds up its tolerance so that if the stressor is applied again, the body is ready for it. This is the basic principle that is, or should be, considered for all types of training.

Similar to the stage of exhaustion in the theory of general adaptation syndrome is the concept of overtraining in sports. Overtraining, according to a joint consensus statement by the European College of Sport Science and the American College of Sports Medicine, can be defined as an "accumulation of training and/or non-training stress that results in long-term decrement in performance capacity with or without related physiological or psychological signs 
and symptoms of maladaptation in which restoration of performance capacity may take several weeks or months" "92. This is different from overreaching in that the "accumulation of training and/or non-training stress results in a short-term decrement in performance capacity with or without related physiological or psychological signs and symptoms of maladaptation". 92 Overreaching may be appropriate in training to elicit a response that, with the appropriate recovery, boosts the capacity of the individual. ${ }^{92}$ These terms are also different from "burnout" and "staleness" although staleness may be closely synonymous with overtraining. Burnout "describes a negative emotional reaction to sport participation whereas staleness indicates a disorder where maladaptive physiological responses to training are present". ${ }^{93}$ In other words, high levels of stress from several external sources such as the physical response from strenuous training or emotional responses to school, friends, and other relationships can affect an individual's performance if not recovered from properly. If these stresses are prolonged, the individual may begin to display adverse physiological and psychological effects, most notably decreases in performance. ${ }^{92}$

Research regarding the prevalence of overtraining and staleness in youth athletes is present. ${ }^{94-99}$ For example, the prevalence of nonfunctional overreaching in young English athletes was $29 \%(N=376)$ with the incidence being higher in individual sports compared to team sports. ${ }^{94}$ Further, about $35 \%$ of adolescent swimmers across various countries $(N=231)$ reported being "stale" for an average length of about 4 weeks. ${ }^{95}$ However, as the aforementioned definition states, non-training stress may play a role in overtraining or overreaching. Gustaffsson et al. ${ }^{96}$ performed a cross-sectional study examining psychological burnout variables in individual and team sport adolescent athletes. The frequency of male athletes participating in team sports scored significantly higher than males participating in individual sports on all 
burnout variables.$^{96}$ Additionally, more males playing team sports were categorized in the high burn out category than their individual sport counterparts. ${ }^{96}$ This was not the same for females, although the differences between groups were small. Further, the frequency of female athletes participating in team sports scored slightly lower on all burnout variables compared to females participating in individual sports. ${ }^{96}$ Regardless of the differences in sample sizes of individual sports and team sports with respect to each gender, these results convey that the psychological stresses can contribute to burnout in team sport athletes. These results were contradictory to arguments made that individual sports require more effort, resources, and time. ${ }^{97,98}$

The implication of overtraining is that it represents the accumulation of too much stress and as a result the body is unable to recover. As high school athletes, the sources of mental and physical stress are vast and may include school, family, friends, homework, sports, and other extracurricular activities. Overtraining or burnout may lead to injury and possibly eventual dropout of youth sport. ${ }^{5}$ Given the many directions that stress can come from, it is not difficult to see that sports specialization could be connected to overtraining, burnout, and overuse injury.

\section{Injury Risk and Underlying Contributions}

Sports specialization has been suggested to be a root association to athletic injuries, especially overuse injury. Jayanthi et al. ${ }^{8}$ studied factors associated with increased risk of youth athletes ages 7-18 years old through a case-control study. Age, degree of specialization, total physical activity time, and total organized sports activity time appeared to be positively associated with injury. ${ }^{8}$ Most importantly, this was the first study to conclude that single-sport specialization was an independent risk factor for injury and "serious overuse injury", but not

acute injuries. Specifically, those who were identified as highly specialized had an increased risk of developing serious overuse injuries (OR, 2.25; CI, 1.27-3.99; $p<.001) .{ }^{8}$ 
The 3-point scale for classifying athletes into sport specialization categories. ${ }^{8}$ The scale determined what category of specialization an athlete was classified into based on the following 3 questions: 1. Do you train in your primary sport 8 or more months out of the year?, 2. Do you consider your primary sport more important than other sports?, 3. Have you quit other sports to focus on your sport?. One point was given for every "yes" an athlete responded with. Three points corresponded with high specialization, 2 points with moderate specialization, and 0 or 1 point with low specialization. ${ }^{8}$ With this in mind, the scale appears to contrast the definition of sport specialization cited by Malina et $\mathrm{al}^{1}$ to some extent. This scale opens the door to multisport athletes by using the phrase "primary sport" thereby suggesting that an athlete can still specialize even if they play multiple sports whereas the definition explicitly states "...one sport year-round at the exclusion of others". ${ }^{1}$ Thus, in the case of the multi-sport athlete, they may still train their primary sport more than 8 months out of the year, consider their primary sport more important than other sports, and have quit another sport to now focus on a primary and secondary sport. Re-assessing the sports specialization definition may prove necessary for future studies.

Other evidence that sport specialization is linked to injury was produced by Hall et al. ${ }^{100}$ suggesting that specializing in a single sport increased the risk of patellofemoral pain syndrome 1.5 times. Strikingly, specific diagnoses such as Osgood Schlatters disease, Sinding-Larsen Johansson disease, and patellar tendinopathy were 4 times as likely to be sustained by single sport athletes than multisport athletes. ${ }^{100}$ Specializing in an individual sport seems to further the risk of injury according to Pasulka et al. ${ }^{101}$ as these individuals sustained more overuse (44.3\% vs $32.3 \%$ ) and serious overuse ( $23.4 \%$ vs $11.6 \%$ ) injuries compared to specialized single sport athletes who participated in team sports. ${ }^{101}$ The authors also reported that the top 3 team sports 
most frequently populated with "single-sport specialized" athletes were the following: soccer, basketball, volleyball. ${ }^{101}$

More recent research has begun to lend support to the notion that specialization is an independent risk factor for injury. ${ }^{10,12}$ One study concluded that club participation outside of high school sports and competition volume were associated with a history of lower extremity injury (LEI). ${ }^{12}$ In the context of the latter, a high annual competition volume ( $>60$ competitions) resulted in a two-fold increase in the odds of an athlete reporting a history of LEI. ${ }^{12}$ The first prospective study about high school athletes and sport specialization was published in $2018 .^{10}$ These authors reported that the incidence rate of sustaining a lower extremity injury in a highly specialized athlete was $85 \%$ compared to athletes in the low specialization category. ${ }^{10}$ Another study funded by the National Federation of State High School Associations (NFHS) reported that athletes were twice as likely to have previously sustained a LEI if they specialized in a single sport compared to those who did not specialize. ${ }^{102}$

High injury risks in youth athletes are not exclusive to sports with a lower body emphasis. A 5-fold increase in injury risk has been reported for adolescent pitchers who pitched 8 or more months out of the year. ${ }^{103}$ In addition, a 4 -fold increase of injury risk was found in those pitchers who pitched more than 80 pitches per game. ${ }^{103}$ Others have noted in a prospective study that pitching more than 100 innings over at least 1 year elevated the odds of sustaining an injury by 3.5 times. ${ }^{104}$ Although these studies did not assess sports specialization within their sample, it must be noted that the playing time throughout the year (i.e. 8 or more months out of the year, 100 innings over at least 1 year) lends evidence to the idea that high volume can lead to overuse injuries. Other research supports this notion that training volume plays a role in overuse injuries especially if sports specialization is a factor. ${ }^{9}$ Eight months or more of participating in 
organized sports appears to be a threshold whereby if above this mark, a young athlete is more likely to be injured. ${ }^{8,9,12}$

Given the definition of sports specialization and the aforementioned evidence, it appears that the specialized athlete invests too much in one sport to the point of adversity. Theoretically, the more sports exposure you receive, the higher the injury risk. This has been quantified in high school adolescents by Rose et al. ${ }^{105}$ The authors contend that as the weekly hours of athletic exposure, defined as the average number of hours per week of participation in the subject's top 3 activities within the past year, exceeded 16, the odds of sustaining a sports injury needing medical treatment elevated 8 -fold. ${ }^{105}$ This is double the odds of sustaining a sports injury if one was to average 7-10 hours of athletic exposure per week. Location of residence, weekly hours of exposure, BMI, and ethnicity all appeared to have a part in the prediction of injury within this study. ${ }^{105}$ However, the study did not use specialization as an independent variable and the researchers asked about athletic exposure in the top 3 activities of each individual. These activities may not all represent organized sport activities. Additionally, it is important to note that sports and recreation injuries (SRI) were collected, which is not specific to injuries resulting from organized sports. Therefore, in regards to sports specialization, these results do not lend much evidence. Despite this, one may conjecture that if an adolescent individual participates in 3 activities for more than 16 hours per week on average thus having an elevated risk of sustaining a sports injury that needs medical treatment, then it may be possible to suggest too much sports physical activity participation is detrimental to adolescent health. An insinuation such as this would then imply that the volume of participation in sports that is the root of injury risk regardless of playing one or multiple sports. 
On the other hand, it may be the absence of rest and recovery that may be the root of these injury rates. One author demonstrated that those who played sports all year long had a $42 \%$ increased risk of sustaining an overuse injury. ${ }^{106}$ This risk was still present regardless of whether the individual played the same sport or played multiple sports throughout the year. ${ }^{106}$ Perhaps a solution to high volumes of training is providing recommendations and implementing practices that allows adolescent athletes time to recover from physical training.

Other factors may have a place putting an athlete at risk for developing an overuse injury such as overscheduling ${ }^{107}$ and socioeconomic status ${ }^{108}$. Dugar et al. ${ }^{108}$ showed that socioeconomic status may play a role in those youth athletes who sustain overuse injuries. Those youth athletes who were part of a family with a higher income are $68 \%$ more likely to sustain overuse injuries than those with a lower income. ${ }^{108}$ In addition, those who could afford private health insurance were twice as likely to be highly specialized in one sport while also showing decreased amount of free play time compared to those with public health insurance. ${ }^{108}$ Thus, if a family has the financial resources to gain access to more training opportunities, the athlete would increase their athletic exposure and therefore the potential for injury. Luke et al. ${ }^{107}$ has described fatigue-related effects of overscheduling and its implication to injury. Increased practice time 48 and 72 hours prior to injury were not associated with fatigue-related injuries. This could be due to multiple factors such as sport format and organization, season of play, lifestyle, as well as activity parameters (i.e. intensity, duration). Overuse injuries were associated with athlete and parent perception of too much play or training without enough rest between sessions. Interestingly, sleeping fewer than 6 hours was related to all fatigue-related (overuse and acute) injuries, but it was not specific to fatigue-related overuse injuries. ${ }^{107}$ 
Clearly, time invested into sports as in the case of a specialized athlete may pose a risk for injury. While injuries will always remain multifactorial, the volume of training must be taken into account with overuse injuries. In an effort to reduce the likelihood of these injuries, the recommendations below have been provided.

\section{Recommendations}

Recommendations about sports specialization are still inconsistent in that more evidence is needed from high quality longitudinal studies. For example, Jayanthi et al. ${ }^{2}$ provided a level "B" evidence from the Strength of Recommendation Taxonomy (SORT) for the statements that sports specialization should be delayed until early adolescence to reduce the risk of injury and psychological stress and that sports specialization is necessary for elite skill development. ${ }^{2}$ Other recommendations include the following: having a total of 3 months off in the calendar in increments of 1 month to allow for recovery and having at least 1-2 days off per week to facilitate recovery and reduce the likelihood of injury. ${ }^{7}$ However, some recommendations such as planning for long-term periodization ${ }^{87}$ may prove unrealistic because this would require hours of training and experience from coaches and parents that is not possible due to financial and time constraints.

\section{Conclusion}

Sports have been a main source of entertainment and expression of physical activity in the United States. High school sports in particular has made an impressive growth in the past century due to political and economic groundworks. Unfortunately, increased participation in sports has led to the need to injury research. Risk factors such as sports specialization has been an issue that needs prompt attention. The risks of injury, exhaustion, and psychological distress need to be weighed against the potential benefits of enhancing one's sports skills, attaining elite 
status, or earning a collegiate scholarship. Specializing in one sport appears to be a double-edged sword. Investing the majority of your time in one activity can result in the sacrifice of time with other social and educational activities. Information regarding sports specialization and its risks must be circulated throughout the sports community in order to inform parents and coaches. By doing so will enable these influential figures to make appropriate decisions and have realistic expectations of youth athletes. Parents serve as one of these influential figures. They're catalyst for sport participation and may influence a child's enjoyment and perceived competence in sport. It is therefore the purpose of this study to provide more information about the characteristics of specialized athletes, what factors parents perceive to be the most influential to their athlete in deciding to pursue a single sport rather than multiple sports, and predict sport specialization classification based on parental beliefs. 


\section{CHAPTER III: METHODS}

\section{Study Design}

This study is of a cross-sectional design through a questionnaire. These questionnaires were adapted with permission from previous authors of sport specialization research. ${ }^{12} \mathrm{We}$ examined the association between parental sport specialization beliefs to high school athlete's sport specialization classification. We also investigated independent correlations between sport specialization classification and parental perceived influential factors that may have played a role in an athlete's pursuit of a single sport.

\section{Participants}

Local school districts were contacted for approval to conduct research within the high schools. The schools were chosen because they were able to represent multiple levels of a sport (varsity, junior varsity, freshmen) and were convenient to the researchers. A comparison of the student body of the 2 high schools can be seen in Table 1. Eligibility criteria required participants to be between 13-18 years old and on a freshman, junior varsity, or varsity high school athletic team roster for the 2017-2018 academic calendar year and a parent or guardian of the student-athlete willing to participate. Participants were recruited from the following sports: boys' soccer, girls' volleyball, girls' basketball, and boys' basketball. We chose these sports because they could be played in multiple seasons and they represented the team sports that most frequently have highly specialized athletes. ${ }^{101}$ Fifty-seven high school student-athletes (25 females, 32 males; mean age 15.6 \pm 1.6 ) selected onto freshmen, junior varsity, or varsity teams of soccer, volleyball, and basketball and their parents (34 females, 23 males; mean age 46.9 \pm 5.2 ) of two large (mean student size $=1,805)$ public suburban schools participated. Descriptive statistics about the student and their parents can be found in Tables 2, 3, and 4. 
Table 1

High School Student Body Demographics

\begin{tabular}{ccc}
\hline School Size & Large* $(\mathrm{n}=1,945)$ & Large* $(\mathrm{n}=1,553)$ \\
\hline School Type & Public & Public \\
White & $70 \%$ & $76 \%$ \\
Black & $10 \%$ & $12 \%$ \\
Hispanic & $7 \%$ & $5 \%$ \\
Islander & $0.2 \%$ & $0.2 \%$ \\
Hawaiian Native/Pacific & $0.3 \%$ & $0.5 \%$ \\
American Indian/Native & $7 \%$ & $1 \%$ \\
Alaskan & $5 \%$ & $5 \%$ \\
Asian & $5 \%$ &
\end{tabular}

Table 2

High School Student-Athlete Characteristics

\begin{tabular}{cccc}
\hline Descriptive & Category & Frequency & Percent $(\%)$ \\
\hline Gender $(\mathrm{n}=57)$ & Male & 32 & 56.1 \\
& Female & 25 & 43.9 \\
Age $(\mathrm{n}=57)$ & 14 years old & 13 & 22.8 \\
& 15 years old & 13 & 22.8 \\
& 16 years old & 14 & 24.6 \\
& 17 years old & 17 & 29.8 \\
Grade $(\mathrm{n}=57)$ & $9^{\text {th }}$ & 16 & 28.1 \\
& $10^{\text {th }}$ & 12 & 21.1 \\
& $11^{\text {th }}$ & 14 & 24.6 \\
& $12^{\text {th }}$ & 15 & 26.3 \\
Self-Sport Classification & Single Sport & 31 & 54.4 \\
& & & \\
& Multi-Sport & 26 & 45.6 \\
\hline
\end{tabular}


Table 3

Parent Age

\begin{tabular}{cccc}
\hline Descriptive & Min, Max & Mean & Standard Deviation \\
\hline Parent Age & 33,59 & 46.9 & 5.2 \\
\hline
\end{tabular}

Table 4

Parent Characteristics

\begin{tabular}{|c|c|c|c|}
\hline Descriptive & Category & Frequency & Percent (\%) \\
\hline \multirow[t]{2}{*}{ Gender $(n=55)$} & Male & 23 & 40.4 \\
\hline & Female & 34 & 59.6 \\
\hline \multirow{3}{*}{$\begin{array}{l}\text { Highest Level of Education } \\
\text { of you or your spouse }(n=55)\end{array}$} & High School/GED & 5 & 8.8 \\
\hline & $\begin{array}{l}\text { 4-year College Degree } \\
\text { (BA/BS) }\end{array}$ & 26 & 45.6 \\
\hline & $\begin{array}{c}\text { Graduate Degree (MS, } \\
\text { MA, MD, PhD, JD, MBA } \\
\text { etc) }\end{array}$ & 24 & 42.1 \\
\hline \multirow{4}{*}{$\begin{array}{l}\text { Highest Level of Organized } \\
\text { Sports Participation }(n=55)\end{array}$} & Did not play sports & 3 & 5.3 \\
\hline & $\begin{array}{c}\text { Pre-High School (youth } \\
\text { leagues }\end{array}$ & 7 & 12.1 \\
\hline & High School & 36 & 63.2 \\
\hline & College & 9 & 15.8 \\
\hline
\end{tabular}




\section{Procedures}

Questionnaires were discussed and disseminated at parent meetings in the beginning of each respective sports' season. In some cases, due to scheduling, surveys were discussed and disseminated directly to the student-athletes to bring home to their parents. Two surveys were given to participants who volunteered to participate - one for the student-athlete to complete and one for a parent or guardian to complete independently of each other. We requested that at least one parent or guardian complete the survey. If a student-athlete had two parents, only one parent completed the survey. If a family had multiple athletes selected onto the same school team, different parents would complete the parent/guardian survey for each child. The questionnaires were cross-referenced between the student-athlete and their parent or guardian through a mutually created identification number in order to maintain anonymity. This study was approved by the Illinois State University Institutional Review Board. Informed assent and consent was acquired before participation.

\section{Instrumentation}

Parents were given a similar survey as the students (see Appendix A and B) detailing their demographics, attitudes and beliefs about sports specialization as well as their studentathlete's sports career characteristics (i.e. volume of play, injury history etc.). The aim of disseminating similar surveys were to cross-reference answers to enhance accuracy of collected data. A glossary of terms and within context definitions were provided to help participants answer the questions within the survey. Further, athletes were classified as "high", "moderate", or "low" specialization categories based on a 3-point scale classification described in previous literature..$^{8,12}$ This scale classifies an athlete at a certain level of sport specialization based on an athlete's response to the following 3 questions: 1 . Do you train more than 8 months out of the 
year?, 2. Do you consider your primary sport more important than other sports, 3. Have you quite other sports to focus on your sport? One point was awarded to each question the athlete answered "yes" to. If an athlete garnered 3-points then they were classified as highly specialized. If they had 2 points then they were moderately specialized and if they had 0 or 1 point then they were considered to be low specialized. The 3-point scale was utilized to delineate sports specialization levels among athletes since the self-classification method presented limitations in previous research. ${ }^{12}$ However, it is recognized that student-athletes may play multiple school sports in one calendar year. Therefore, participants were asked to self-designate themselves as single or multisport athletes. Participants were classified using the 3-point scale regardless of multi-sport or single sport designation.

\section{Statistical Analyses}

Overall data was summarized in terms of means, standard deviations $( \pm \mathrm{SD})$, frequencies and percentages, and odds ratios (ORs). Correlation analyses were used to detect associations between level of specialization and parent perceived influential factors driving their athlete's decision to pursue a single sport only in those athletes who self-selected themselves as singlesport athletes. Two separate ordinal regressions were used to predict student athlete's classification of specialization based on parent's beliefs towards sport specialization. We used the following two questions to define a parent's belief towards sport specialization: "Do you think early sport specialization is a problem in youth sports?" and "rate your agreement with the following: participating year-round in a single sport increases my child's chance of sustaining an overuse injury". A parent's response towards each questions represented our independent variable while student-athlete classification of sport specialization based on parent responses was 
used as our dependent variable. Alpha level was set at $p<0.05$. All statistical analyses were completed with SPSS statistical software (v 24.0; IBM Corp).

\section{Data Reduction}

Of the 57 parents who were included in the regression analyses, only 1 data point was missing due to incompleteness of that parent survey. Frequencies of each sport specialization category and parent's responses to the questions used as data points in the ordinal regression can be found in Tables A1, A3, and A4.

Due to the small sample size of the study, responses to the questions used to identify parental beliefs towards sport specialization were merged into the following: "disagree", "no opinion", "agree"; "not a problem”, "no opinion", “a problem”. This was performed in preparation for the regression analyses. 


\section{CHAPTER IV: RESULTS}

The ordinal regression analyses demonstrated that each final model did not have a significant improvement over the general model $\left(\chi^{2}=0.68, \mathrm{df}=2, \mathrm{p}=0.71, \chi^{2}=5.51, \mathrm{df}=2, \mathrm{p}=0.06\right)$ (Table A5). This result is amplified by the pseudo $\mathrm{R}^{2}$ values, which indicate that parent's category of agreement trivially explains an athlete's level of classification (pseudo- $\mathrm{R}^{2}$ : Nagelkerke=.014). This also appears to be the case in the context of parent's belief that early sport specialization is a problem (pseudo- $\mathrm{R}^{2}$ : Nagelkerke= 106 ). In addition, the odds ratios between levels of specialization based on parental beliefs were not consistent (Table A6). When a parent responded that early sport specialization was "a problem", the odds of a student athlete being classified as highly specialized was 3.22 times higher than if a parent responded that early sport specialization was "not a problem". Further, when a parent responded that they "agreed" with participating in one organized sport year-round increases their child's likelihood of sustaining an overuse injury, the odds of a student athlete being classified as highly specialized was 1.51 higher than if the parent responded they had "no opinion" on the matter (Table A6). In regards to the study's second objective, factors perceived by parents as influential in determining a student athlete's decision to pursue a single sport are the following: need to stay competitive with other children $\left(\mathrm{r}_{\mathrm{s}}=0.636, p=0.01\right)$, better chance to receive a scholarship/contract $\left(\mathrm{r}_{\mathrm{s}}=0.501\right.$, $p=0.01)$. 


\section{CHAPTER V: DISCUSSION}

Previous research has attempted to quantify parental influence in regards to specialization. ${ }^{14}$ Approximately $18 \%$ of specialized parents admitted to influencing their child to specialize "a lot" or "very much". ${ }^{14}$ Since parents appear to exert some level of influence over their children's sporting careers, we attempted to see if parent's beliefs towards sport specialization could explain how their child was classified. The following two questions were used to describe parental beliefs towards sport specialization: 1. Do you think early sport specialization is a problem in youth sports; 2 . Rate your agreement to the following: playing a sport year-round increases my child's risk of sustaining an overuse injury. Each of the aforementioned questions have gained a substantial amount of evidence-based recommendations and perspectives - most of them warning about the risks associated with specializing. ${ }^{3,4,6-12}$ Our results did not support our hypothesis in that parental sport specialization beliefs were associated with athlete sport specialization classification given that each model was not able to predict better outcomes over the general model. However, two important points to take away from this study are the following: the odds of an athlete being moderately or highly specialized when parents responded that early sports specialization is "a problem" in youth sports is 3.22 than if a parent responded "not a problem" and the odds of an athlete being moderately or highly specialized when parents respond that they "agree" that their child's likelihood of sustaining an overuse injury is increased if they play one organized sport year-round is 1.51 more times than if their parent had "no opinion" on the matter. This appears counterintuitive as one may think that if a parent believes early sport specialization is a problem then they would be less inclined to have their athlete be highly specialized. Similarly, only $41 \%(n=23)$ of parents, regardless of their child's specialization classification, in this sample agreed that playing one sport year-round 
increases their child's odds of sustaining an overuse injury. Of those parents who responded "agree", 34\% (n=8) classified their child as being highly specialized. Thus, it would appear that even though some parents agree that their child has an increased risk of sustaining an overuse injury, it may not be influential enough to curb their athlete's year-round participation in one organized sport. Perhaps parents believe that high school is the time to express interest in one sport in order to boost one's athletic collegiate career chances thereby outweighing the risk. Further, with "no opinion" being the next frequent response, it may signify that parents do not have enough information about the topic to be able to form an opinion.

Sport specialization is defined as "intense training of one sport year-round exclusively". ${ }^{1,2}$ While this definition has been consistently utilized in the literature ${ }^{8-12}$, it is difficult to quantify the parameter "year-round". It appears that playing one sport 8 months or more out of the calendar year puts an athlete at an increased risk for sustaining any injury ${ }^{9,11,12}$, especially lower extremity. ${ }^{10}$ It thus seems plausible that 8 or more months may be more accurate than "year-round" when identifying highly specialized athletes. Further, the phrase "intense training" may give rise to a debate about what constitutes training as opposed to "playing". These phrases may pose different interpretations. Training may be seen as practice with the intent of trying to improve one's game whereas playing may be interpreted as unorganized recreation. In addition, labeling the participation in sports as organized or unorganized can refer to different styles of play; the former being more supervised and structured while the latter is less so. Previous research has suggested that sports specialization is on a continuum rather than two sides of coin. ${ }^{8,12}$ Jayanthi et al. ${ }^{8}$ developed a 3-point scale on how to classify sport specialization as opposed to self-classification. This study adopted this same method to establish consistency with other research. However, previous literature looking at parental influence on athlete sport 
specialization did not adopt this method. ${ }^{14}$ Instead, they had parents assign their own athlete's level of specialization using the authors own scale interpretation: "one sport only" (highly specialized), "multiple sports but has a favorite" (moderately specialized), "enjoys all sports equally" (low specialization) ${ }^{14}$ This may introduce some level of social desirability bias whereas using the 3-point scale disguises how an athlete is classified assuming the parents don't know how it's utilized. How these terms are constructed and therefore how sport specialization is classified will dictate future research. Accurate definitions of terms must be continually reevaluated if research is to use them to identify athletes of interest. This assessment will also aid in the education of athletes, parents, and coaches as more recommendations are drawn from research studies.

Previous literature has linked decreased sport enjoyment to external pressure from parents. ${ }^{12}$ This pressure has been defined as "pushing children to compete and continue to practice their skills" ${ }^{57,114}$ External pressure has also demonstrated positive associations with stress and negative associations with enjoyment and motivation..$^{57,114}$ Conversely, parental support has been positively related to sport participation and self-esteem. ${ }^{57,113}$ Coaches also appear to be an additional source of pressure, especially in the context of persuading an athlete to cease playing other sports. ${ }^{13}$ However, not all coaches may share this perspective. Recent research showed that approximately $67 \%(\mathrm{n}=170)$ of youth sport coaches believed that yearround participation in a single sport was either "very" or "extremely" likely to increase an athlete's injury risk. ${ }^{116}$

The attempt at predicting high school athlete's level of specialization may parallel a recent study examining specialization patterns of D1 collegiate athletes. ${ }^{111}$ The authors found that only $9.9 \%(n=34)$ of athletes cited that parental influence was the number one reason for 
deciding to specialize in a collegiate sport. ${ }^{111}$ In fact, the top 3 reasons these athletes decided to specialize were the following: they enjoyed that sport the most, there was an opportunity to receive a scholarship or contract within that sport, and they perceived themselves as having a high level of competence in that sport. ${ }^{111}$ These results may parallel our correlational analyses, which established that a "better chance to receive a scholarship/contract" was the second most positively related influential factor for a student-athlete deciding to pursue a single sport as perceived by their parents. Therefore, it may be that parental influence plays less of a role in athlete's decision to pursue a single sport.

Future research in further examining the role of parental influence in high school sport specialization should involve high schools with different sizes and diverse populations. The extent of parent's influence on student-athlete participation in team sports compared to individual sports should also be examined. Other external influences such as coaches and the media should be explored directly through high school student-athletes. Additionally, intrinsically motivating factors such as enjoyment of sport, competence level within a sport, and social aspects of sports should be investigated to capture the full picture as to why athlete's decide to pursue a single sport.

\section{Limitations}

The major limitation to this study is the small sample size. This greatly influenced our ability to conduct the ordinal regression since not all groups could be represented. This created inconsistencies within our odds ratios and we could not establish a consistent proportion between each level. The study design was also cross-sectional. Therefore, it is subject to maturation bias in that parent's beliefs towards sport specialization may have evolved over time, especially as new information begins to reach the sporting communities. Another area of limitation is in our 
recruitment strategy. Only large public suburban schools were included and recent research has shown that these high schools are more likely to contain highly specialized athletes. ${ }^{15}$ This may have inflated our frequency of highly specialized athletes thereby misrepresenting opinions of parents whose child is less specialized or live in urban or other communities. Selection bias may also have played a role in this study as the teams athletes were recruited from were known to be populated with highly specialized athletes according to previous research. ${ }^{101}$ Further, characteristics of the sample such as race and ethnicity were not taken into account and therefore do not represent the student body of each school. 


\section{CHAPTER VI: CONCLUSION}

To our knowledge, this is the first study to ascertain to what degree parents influence their child's level of sport specialization. Our results indicate that a parent's attitude towards sport specialization was not able to predict or explain their child's specialization classification. In other words, even though parents agreed to some extent that participating in one sport year-round increased their child's chances of sustaining an overuse injury or believed that early sports specialization was a problem, it did not affect their athlete's decision to specialize. 


\section{REFERENCES}

1. Malina RM. Early Sport Specialization: Roots, Effectiveness, Risks. Curr Sports Med Rep. 2010;9(6):364-371. doi:10.1249/JSR.0b013e3181fe3166.

2. Jayanthi N, Pinkham C, Dugas L, Patrick B, LaBella C. Sports Specialization in Young Athletes Evidence-Based Recommendations. Sports Health. 2013;5(3):251-257. doi:10.1177/1941738112464626.

3. McLeod TC et al. National Athletic Trainers' Association Position Statement: Prevention of Pediatric Overuse Injuries. J Athl Train. 2011;46(2):206-220.

4. LaPrade RF, Agel J, Baker J, et al. AOSSM Early Sport Specialization Consensus Statement. Orthop J Sports Med. 2016;4(4). doi:10.1177/2325967116644241

5. DiFiori JP, Benjamin HJ, Brenner J, et al. Overuse Injuries and Burnout in Youth Sports: A Position Statement from the American Medical Society for Sports Medicine. Clin J Sport Med. 2014;24(1):3-20. doi:10.1097/JSM.0000000000000060.

6. American Academy of Pediatrics Committee on Sports Medicine and Fitness. Intense training and sports specialization in young athletes. Pediatrics. 2000;106:154-157.

7. Brenner JS, Fitness C on SMA. Sports Specialization and Intensive Training in Young Athletes. Pediatrics. 2016;138(3):e20162148. doi:10.1542/peds.2016-2148

8. Jayanthi NA, LaBella CR, Fischer D, Pasulka J, Dugas LR. Sports-Specialized Intensive Training and the Risk of Injury in Young Athletes A Clinical Case-Control Study. Am J Sports Med. 2015;43(4):794-801. doi:10.1177/0363546514567298.

9. Post EG, Trigsted SM, Riekena JW, et al. The Association of Sport Specialization and Training Volume With Injury History in Youth Athletes. Am J Sports Med. 2017. doi:10.1177/0363546517690848.

10. McGuine TA, Post EG, Hetzel SJ, Brooks MA, Trigsted S, Bell DR. A Prospective Study on the Effect of Sport Specialization on Lower Extremity Injury Rates in High School Athletes. Am J Sports Med. 2017;45(12):2706-2712. doi:10.1177/0363546517710213

11. Bell DR, Post EG, Trigsted SM, Hetzel S, McGuine TA, Brooks MA. Prevalence of Sport Specialization in High School Athletics A 1-Year Observational Study. Am J Sports Med. 2016;44(6):1469-1474. doi:10.1177/0363546516629943

12. Post EG, Bell DR, Trigsted SM, et al. Association of Competition Volume, Club Sports, and Sport Specialization With Sex and Lower Extremity Injury History in High School Athletes. Sports Health. 2017;9(6):518-523. doi:10.1177/194173811771416013.

13. S. Padaki A, Popkin C, L. Hodgins J, Kovacevic D, Lynch TS, Ahmad C. Factors That Drive Youth Specialization. Sports Health. October 2017:194173811773414.

doi: $10.1177 / 1941738117734149$ 
14. Padaki AS, Ahmad CS, Hodgins JL, Kovacevic D, Lynch TS, Popkin CA. Quantifying Parental Influence on Youth Athlete Specialization: A Survey of Athletes' Parents. Orthop J Sports Med. 2017;5(9). doi:10.1177/2325967117729147

15. Meyers S. Estimated probability of competing in college athletics. NCAA.org - The Official Site of the NCAA. http://www.ncaa.org/about/resources/research/estimated-probabilitycompeting-college-athletics. Published March 2, 2015. Accessed April 5, 2017.

16. Powell R. Estimated probability of competing in professional athletics. NCAA.org - The Official Site of the NCAA. http://www.ncaa.org/about/resources/research/estimatedprobability-competing-professional-athletics. Published March 6, 2015. Accessed April 5,2017

17. Matthew T. Bowers, Laurence Chalip, B. Christine Green. The United States of America. In: Nicholson M, Hoye R, Houlihan B, eds. Participation in Sports: International Policy Perspectives. New York, NY: Routledge; 2011: Chapter 16.

18. Weiss MR, Hayashi, CT. The United States. In: De Knop P, Engström LM, Skirstad B, Weiss MR, eds. Worldwide Trends in Youth Sport. Champaign, IL: Human Kinetics; 1996: Chapter 5.

19. Woods, RB. Social Issues in Sport. Champaign, IL: Human Kinetics; 2011.

20. Reutter, E. The Law of Public Education, 4th ed. Westbury, N.Y: Foundation Press, Inc. 1994.

21. Forsyth E, Olson J. Priority Issues Ahead in Interscholastic Sports. In: Blackburn ML, Forsyth E, Olson J, Whitehead B, eds. NIAAA's Guide to Interscholastic Athletic Administration. Champaign, IL: Human Kinetics; 2013: Closing.

22. Buckanavage B. Marketing and Fundraising. In: Blackburn ML, Forsyth E, Olson J, Whitehead B, eds. NIAAA's Guide to Interscholastic Athletic Administration. Champaign, IL: Human Kinetics; 2013: Chapter 13.

23. Riddle, G. Club Sports Offer Exposure - But at a Steep Price. The Dallas Morning News. http://res.dallasnews.com/interactives/club-sports/part3/. Published 2014. Accessed March $17^{\text {th }}, 2017$.

24. Butler, S. $\$ 4,000$ to Play Youth Baseball: Kids' Sports Costs Are Out of Control. CBS Money Watch. http://www.cbsnews.com/news/4000-for-youth-baseball-kids-sportscosts-are-out-of-control/. Published April 2011. Accessed March 17 $7^{\text {th }}, 2017$.

25. Blumerman, L. Education Funding: Where do Schools Get Their Money? How do They Spend it?. United States Census Bureau. http://blogs.census.gov/2012/06/21/educationfunding-where-do-schools-get-their-money-how-do-they-spend-it/. Published June 2012. Accessed March 13, 2017. 
26. Coakley J. Using Sports to Control Deviance and Violence among Youths: Let's be Critical and Cautious. In: Gatz M, Messner MA, Ball-Rokeach SJ. Paradoxes of Youth and Sport. Albany, NY: State University of New York Press; 2002: pp. 13-30.

27. University of Michigan Health System. Pay-to-play sports keeping lower income kids out of the game. Science Daily. https://www.sciencedaily.com/releases/2012/05/120514104945.htm. Published May 2012. Accessed March $18^{\text {th }}, 2017$.

28. Zdorik J, Veliz P. The Influence of Pay to Play Fees on Participation in Interscholastic Sports: A School-Level Analysis of Michigan's Public Schools. J Phys Act Health. 2016;13(2):1317-1324. doi: 10.1123/jpah.2016-0099

29. Leachman M, Albares N, Masterson K, Wallace M. Most States Have Cut School Funding, and Some Continue Cutting. Center on Budget and Policy Priorities. http://www.cbpp.org/research/state-budget-and-tax/most-states-have-cut-school-fundingand-some-continue-cutting. Published December 2015. Accessed March 13, 2017.

30. The Sports and Fitness Industry Association via Sports Marketing Surveys. 2013 Sports, Fitness, and Leisure Activities Topline Participation Report (pdf). http://www.espn.com/pdf/2013/1113/espn_otl_sportsreport.pdf. Published 2013. Accessed March 12, 2017.

31. Vandenbroucke G. Trends in Hours: The U.S. from 1900 to 1950. J Econ Dyn Control. 2009;33(1):237-249. https://papers.ssrn.com/abstract=1143584. Accessed March 17, 2017.

32. Bureau of Labor Statistics: U.S. Department of Labor. American Time Use Survey - 2014 Results. https://www.bls.gov/news.release/archives/atus_06242015.pdf. Published June 2015. Accessed March $17^{\text {th }}, 2017$.

33. Baran, SJ. The Museum of Broadcast Communications: Sports and Television. http://www.museum.tv/eotv/sportsandte.htm. Accessed March 17th, 2017.

34. Quirk J, Fort R. HARD BALL: The Abuse of Power in Pro Team Sports. In: Gratton C, Solberge HA. The economics of sports broadcasting. New York, NY: Routledge. 2007: p. 1.

35. Cohany, SR, Sok, E. Trends in labor force participation of married mothers of infants. Mon Labor Rev. 2007;130:9-16. https://www.bls.gov/opub/mlr/2007/02/art2full.pdf. Accessed March $8^{\text {th }}, 2017$.

36. Snyder, Howard N. and Mulako-Wangota, Joseph. Bureau of Justice Statistics. Juvenile Arrest Rates for Violent Crime Index Offenses 1980-2012. Generated using the Arrest Data Analysis Tool. https://www.bjs.gov/index.cfm?ty=datool\&surl=/arrests/index.cfm. Accessed March 13th, 2017. 
37. The National Federation of State High School Associations (NFHS). 2014-15 High School Athletics Participation Survey (pdf). https://www.nfhs.org/ParticipationStatistics/PDF/201415_Participation_Survey_Results.pdf. Published 2015. Accessed March 6 ${ }^{\text {th }}, 2017$.

38. National Interscholastic Athletic Administrators Association. Survey provides new information on high school athletics. http://www.miaa.net/NIAAA-Survey-pressrelease.pdf. Published October 2006. Accessed March 24th, 2017.

39. Seefeldt V, Ewing M, Walk S. Youth Sports in America: An Overview. President's Council on Physical Fitness and Sports Research Digest. 1997;2(11):1-14. http://files.eric.ed.gov/fulltext/ED413324.pdf. Accessed on March 24th, 2017.

40. Bussell LA, Pierce D. National Survey of Interscholastic Sport Sponsorship in the United States. SMIJ. 2011;7(1):43-62. doi: 10.4127/ch.2011.0054

41. International Events Group. Sponsorship Spending Report: Where the Dollars are Going and Trends for 2015. http://www.sponsorship.com/ieg/files/4e/4e525456-b2b1-4049-bd5103d9c35ac507.pdf. Published 2015. Accessed March 24 $4^{\text {th }}, 2017$.

42. Seefeldt V, Ewing M, Walk S. Overview of Youth Sports Programs in the United States. Carnegie Council on Adolescent Development. Washington D.C. 1993.

43. The United States Census Bureau. Statistical Abstract of the United States section 31: $20^{\text {th }}$ century statistics. https://www.census.gov/library/publications/1999/compendia/statab/119ed.html. Published December 1999. Updated September 2015. Accessed March 15 ${ }^{\text {th }}, 2017$

44. The College Board. Trends in Higher Education: Tuition and Fees and Room and Board Over Time, 1976-77 to 2016-17. https://trends.collegeboard.org/college-pricing/figurestables/tuition-and-fees-and-room-and-board-over-time-1976-77_2016-17-selected-years. Accessed March 15 ${ }^{\text {th }}, 2017$

45. NCAA Research. Estimated Probability of Competing in Athletics Beyond the High School Interscholastic Level. https://www.ncaa.org/sites/default/files/2015\%20Probability\%20Chart\%20Web\%20PDF _draft5.pdf. Published in 2013. Last updated April 2015. Accessed January $19^{\text {th }}, 2017$.

46. ScholarshipStats.com. Chances of a High School Athlete getting an Athletic Scholarship. http://www.scholarshipstats.com/scholarshipodds.html. Published 2013. Accessed April $7^{\text {th }}, 2017$.

47. National Federation of State High School Associations. NFHS. High School Sports Participation Increases for the $27^{\text {th }}$ Consecutive Year. 2016; 2014-2015 High School Athletics Participation Survey. NFHS

48. Coakley J. The Good Father: Parental Expectations and Youth Sports. Leisure Stud. 2006;25(2):153-163. doi:10.1080/02614360500467735 
49. Linver MR, Roth JL, Brooks-Gunn J. Patterns of adolescents' participation in organized activities: Are sports best when combined with other activities? Dev Psychol. 2009;45(2):354-367. doi:10.1037/a0014133.

50. Wankel LM, Sefton JM. A Season-Long Investigation of Fun in Youth Sports. J Sport Exerc Psychol. 1989;11(4):355-366. doi:10.1123/jsep.11.4.355.

51. Klint KA, Weiss MR. Perceived Competence and Motives for Participating in Youth Sports: A Test of Harter's Competence Motivation Theory. JSP. 1987;9(1):55-65. doi:10.1123/jsp.9.1.55.

52. Ullrich-French S, Smith AL. Perceptions of relationships with parents and peers in youth sport: Independent and combined prediction of motivational outcomes. Psychol Sport Exerc. 2006;7(2):193-214. doi:10.1016/j.psychsport.2005.08.006.

53. Wankel LM, Kreisel PSJ. Factors Underlying Enjoyment of Youth Sports: Sport and Age Group Comparisons. JSP. 1985;7(1):51-64. doi:10.1123/jsp.7.1.51.

55. Côté J. The Influence of the Family in the Development of Talent in Sport. Sport Psychol. 1999;13(4):395-417. doi:10.1123/tsp.13.4.395.

56. Danioni F, Barni D, Rosnati R. Transmitting Sport Values: The Importance of Parental Involvement in Children's Sport Activity. Eur J Psychol. 2017;13(1):75-92. doi:10.5964/ejop.v13i1.1265.

57. Leff SS, Hoyle RH. Young athletes' perceptions of parental support and pressure. J Youth Adolesc; New York. 1995;24(2):187.

58. Crane J, Temple V. A systematic review of dropout from organized sport among children and youth. Eur Phys Educ Rev. 2015;21(1):114-131. doi:10.1177/1356336X14555294.

59. Kanters M, Bocarro J, Casper J. Supported or Pressured? An Examination of Agreement Among Parent's and Children on Parent's role in Youth Sport. J of Sport Behavior. 2008;31(1): 64-80.

60. Comstock RD, Currie DW, Pierpoint LA. Summary Report National High School SportsRelated Injury Surveillance Study 2014-2015 school year.

61. Mechelen WV, Hlobil H, Kemper HCG. Incidence, Severity, Aetiology and Prevention of Sports Injuries. Sports Med. 1992;14(2):82-99. doi:10.2165/00007256-199214020-00002.

62. Theisen D, Malisoux L, Seil R, Urhausen A. Injuries in Youth Sports: Epidemiology, Risk Factors, and Prevention. Dtsch Z Sportmed. 2014;65:248-252

63. Bittencourt NFN, Meeuwisse WH, Mendonça LD, Nettel-Aguirre A, Ocarino JM, Fonseca ST. Complex systems approach for sports injuries: moving from risk factor identification to injury pattern recognition-narrative review and new concept. Br J Sports Med. 2016;50(21):1309-1314. doi:10.1136/bjsports-2015-095850. 
64. Centers for Disease Control and Prevention (CDC). Sports-Related Injuries Among High School Athletes --- United States, 2005-06 School Year. MMWR Morb Mortal Wkly Rep. 2006;55(38):1037-1040.

65. Knowles SB, Marshall SW, Miller T, et al. Cost of injuries from a prospective cohort study of North Carolina high school athletes. Inj Prev. 2007;13(6):416-421. doi:10.1136/ip.2006.014720.

66. Darrow CJ, Collins CL, Yard EE, Comstock RD. Epidemiology of Severe Injuries Among United States High School Athletes. Am J Sports Med. November 2016. doi: $10.1177 / 0363546509333015$.

67. Rechel JA, Yard EE, Comstock RD. An Epidemiologic Comparison of High School Sports Injuries Sustained in Practice and Competition. J Athl Train. 2008;43(2):197-204.

68. Rechel JA, Collins CL, Comstock RD. Epidemiology of injuries requiring surgery among high school athletes in the United States, 2005 to 2010. J Trauma. 2011;71(4):982-989. doi:10.1097/TA.0b013e318230e716.

69. Roos KG, Marshall SW, Kerr ZY, et al. Epidemiology of Overuse Injuries in Collegiate and High School Athletics in the United States. Am J Sports Med. 2015;43(7):1790-1797. doi: $10.1177 / 0363546515580790$.

70. Dalton SE. Overuse injuries in adolescent athletes. Sports Med. 1992;13(1):58-70.

71. Stein CJ, Micheli LJ. Overuse Injuries in Youth Sports. Phys Sportsmed. 2010;38(2):102108. doi: $10.3810 / \mathrm{psm} .2010 .06 .1787$.

72. Arnold A, Thigpen CA, Beattie PF, Kissenberth MJ, Shanley E. Overuse Physeal Injuries in Youth Athletes. Sports Health. February 2017:1941738117690847. doi: $10.1177 / 1941738117690847$.

73. Emery CA. Risk factors for injury in child and adolescent sport: a systematic review of the literature. Clin J Sport Med. 2003;13(4):256-268.

74. Emery C, Tyreman H. Sport participation, sport injury, risk factors and sport safety practices in Calgary and area junior high schools. Paediatr Child Health. 2009;14(7):439-444.

75. Nilstad A, Andersen TE, Bahr R, Holme I, Steffen K. Risk Factors for Lower Extremity Injuries in Elite Female Soccer Players. Am J Sports Med. 2014;42(4):940-948. doi: $10.1177 / 0363546513518741$.

76. Hewett TE, Myer GD, Ford KR, et al. Biomechanical Measures of Neuromuscular Control and Valgus Loading of the Knee Predict Anterior Cruciate Ligament Injury Risk in Female Athletes A Prospective Study. Am J Sports Med. 2005;33(4):492-501. doi: $10.1177 / 0363546504269591$. 
77. Shin CS, Chaudhari AM, Andriacchi TP. Valgus Plus Internal Rotation Moments Increase Anterior Cruciate Ligament Strain More Than Either Alone. Med Sci Sports Exerc. 2011;43(8):1484-1491. doi:10.1249/MSS.0b013e31820f8395.

78. Hollman JH, Ginos BE, Kozuchowski J, Vaughn AS, Krause DA, Youdas JW. Relationships between knee valgus, hip-muscle strength, and hip-muscle recruitment during a singlelimb step-down. J Sport Rehabil. 2009;18(1):104-117.

79. O’Kane JW, Tencer A, Neradilek M, Polissar N, Sabado L, Schiff MA. Is Knee Separation During a Drop Jump Associated With Lower Extremity Injury in Adolescent Female Soccer Players? Am J Sports Med. 2016;44(2):318-323. doi:10.1177/0363546515613076.

80. Jayanthi NA, Pinkham C, Durazo-Arivu R, Dugas L, Luke A. The risks of sports specialization and rapid growth in young athletes. Clin J Sports Med. 2011;21(2):157.

81. Bloom BS. (1985b). Generalizations about talent development. Developing talent in young people. pp.507-549. NewYork: Ballantine Books

82. Ericsson KA, Krampe RT, Tesch-Römer C. The role of deliberate practice in the acquisition of expert performance. Psychol Rev. 1993;100(3):363-406. doi:10.1037/0033295X.100.3.363.

83. Gould D. Early Sport Specialization. J Phys Educ Recreat Dance. 2010;81(8):33-37. doi: 10.1080/07303084.2010.10598525.

84. Coakley J. The "Logic"of Specialization. J Phys Educ Recreat Dance. 2010;81(8):16-25. doi: 10.1080/07303084.2010.10.

85. Gould D, Carson S. Fun and Games? Myths Surrounding the role of youth sports in developing Olympic Champions. Youth Studies Australia. 2004; 23(1):19-25.

86. Gould D. The Professionalization of Youth Sports: It's Time to Act! Clin J Sports Med. 2009;19(2):81-82. doi:10.1097/JSM.0b013e31819edaff.

87. Wiersma L. Risk and Benefits of Youth Sport Specialization: Perspectives and Recommendations. Pediatr. Exerc. Sci. 2000;12: 13-22.

88. Warburton DER, Nicol CW, Bredin SSD. Health benefits of physical activity: the evidence. CMAJ. 2006;174(6):801-809. doi:10.1503/cmaj.051351.

89. Strong WB, Malina RM, Blimkie CJR, et al. Evidence Based Physical Activity for Schoolage Youth. J Pediatr. 2005;146(6):732-737. doi:10.1016/j.jpeds.2005.01.055.

90. Janssen I, LeBlanc AG. Systematic Review of the health benefits of physical activity and fitness in school age-children and youth. Int. J of Behav. Nutri. And Phys. Activity. 2010;7:40 doi: 10.1186/1479-5868-7-40. 
91. Selye H, Neylan TC. A syndrome produced by diverse nocuous agents. Nature. 1936;138:32.

92. Prevention, Diagnosis, and Treatment of Overtraining Syndrome: Joint Consensus Statement of the European College of Sport Science and the American College of Sports Medicine. Med Sci Sports Exerc. 2013; 41(1): 186-205 doi: 10.1249/MSS.0b013e318279a10a.

93. Raglin JS, Wilson G.S. Overtraining in athletes. In: Hanin Y (Ed.), Emotions in sport (pp. 191-207). Champaign, IL: Human Kinetics; 2000.

94. Matos NF, Winsley RJ, Williams CA. Prevalence of nonfunctional overreaching/overtraining in young English athletes. Med Sci Sports Exerc. 2011;43(7):1287-1294. doi:10.1249/MSS.0b013e318207f87b.

95. Raglin J, Sawamura S, Alexiou S, Hassmén P, Kenttä G. Training Practices and Staleness in 13-18-Year-Old Swimmers: A Cross-Cultural Study. Pediatr Exerc Sci. 2000;12(1):6170. doi:10.1123/pes.12.1.61.

96. Gustafsson H, Sagar SS, Stenling A. Fear of failure, psychological stress, and burnout among adolescent athletes competing in high level sport. Scand J Med Sci Sports. November 2016:n/a-n/a. doi:10.1111/sms.12797.

97. Coakley J. Burnout among Adolescent Athletes: A Personal Failure or Social Problem? Sociology of Sport Journal. 1992;9(3):271-285. doi:10.1123/ssj.9.3.271.

98. Smith RE. Toward a Cognitive-Affective Model of Athletic Burnout. JSP. 1986;8(1):36-50. doi:10.1123/jsp.8.1.36.

99. Kenttä G, Hassmén P, Raglin JS. Training practices and overtraining syndrome in Swedish age-group athletes. Int J Sports Med. 2001;22(6):460-465. doi:10.1055/s-2001-16250.

100. Hall R, Barber Foss K, Hewett TE, Myer GD. Sport specialization's association with an increased risk of developing anterior knee pain in adolescent female athletes. $J$ Sport Rehabil. 2015;24(1):31-35. doi:10.1123/jsr.2013-0101.

101. Pasulka J, Jayanthi N, McCann A, Dugas LR, LaBella C. Specialization patterns across various youth sports and relationship to injury risk. Phys Sportsmed. March 2017. doi:10.1080/00913847.2017.1313077.

102. Howard B. Injury Rates Higher for Athletes Who Specialize in One Sport. NFHS. http://www.nfhs.org/articles/injury-rates-higher-for-athletes-who-specialize-in-onesport/. Published December 2016. Accessed May 17 $7^{\text {th }}, 2017$.

103. Olsen SJ, Fleisig GS, Dun S, Loftice J, Andrews JR. Risk Factors for Shoulder and Elbow Injuries in Adolescent Baseball Pitchers. Am J Sports Med. 2006;34(6):905-912. doi: $10.1177 / 0363546505284188$.

104. Fleisig GS, Andrews JR, Cutter GR, et al. Risk of serious injury for young baseball pitchers: a 10-year prospective study. Am J Sports Med. 2011;39(2):253-257. doi: $10.1177 / 0363546510384224$. 
105. Rose SM, Emery CA, Meeuwisse WH. Sociodemographic Predictors of Sports Injury in Adolescents. Med Sci Sports Exerc. 2008;40(3):444-450.

doi:10.1249/MSS.0b013e31815ce61a.

106. Cuff S, Loud K, O’Riordan MA. Overuse Injuries in High School Athletes. Clinical Pediatrics. 2010;49(8):731-736. doi:10.1177/0009922810363154.

107. Luke A, Lazaro RM, Bergeron MF, et al. Sports-related injuries in youth athletes: is overscheduling a risk factor? Clin J Sport Med. 2011;21(4):307-314. doi:10.1097/JSM.0b013e3182218f71.

108. Dugar L, Jayanthi N, Austin A, et al. Young athletes from higher income families more likely to suffer serious overuse injuries. International Olympic Committee World Conference on Prevention of Injury \& Illness in Sport. 2014. In: Medical Daily. Caba J. Athletes from Rich Families Are 68\% More likely to suffer an injury due to overuse compared to athletes from low-income families. http://www.medicaldaily.com/athletesrich-families-are-68-more-likely-suffer-injury-due-overuse-compared-athletes-lowincome. Published 2014. Accessed May 22nd 2017.

109. US News \& World Report. The Student Body at Normal Community High School in Normal, IL. https:/www.usnews.com/education/best-highschools/illinois/districts/mclean-county-usd-5/normal-community-high-school6897/student-body. Published 2014. Accessed March 25, 2017.

110. US News \& World Report. The Student Body at Normal Community West High School in Normal, IL. https://www.usnews.com/education/best-highschools/illinois/districts/mclean-county-usd-5/normal-community-west-high-school6896/student-body. Published 2014. Accessed March 25, 2017.

111. Post EG, Thein-Nissenbaum JM, Stiffler MR, et al. High School Sport Specialization Patterns of Current Division I Athletes. Sports Health. 2017;9(2):148-153. doi: $10.1177 / 1941738116675455$

112. Amado D, Sánchez-Oliva D, González-Ponce I, Pulido-González JJ, Sánchez-Miguel PA. Incidence of Parental Support and Pressure on Their Children's Motivational Processes towards Sport Practice Regarding Gender. PLOS ONE. 2015;10(6):e0128015. doi:10.1371/journal.pone.0128015

113. Hoyle RH, Leff SS. The role of parental involvement in youth sport participation and performance. Adolescence. 1997;32(125):233-243.

114. O'Rourke DJ, Smith RE, Smoll FL, Cumming SP. Relations of Parent- and CoachInitiated Motivational Climates to Young Athletes' Self-Esteem, Performance Anxiety, and Autonomous Motivation: Who Is More Influential? J Appl Sport Psychol. 2014; 26(4): 395-408 
115. Bell DR, Post EG, Trigsted SM, et al. Sport Specialization Characteristics Between Rural and Suburban High School Athletes. Orthop J Sports Med. 2018;6(1):2325967117751386. doi:10.1177/2325967117751386

116. Post EG, Trigsted SM, Schaefer DA et al. Knowledge, Attitudes, and Beliefs of Youth Sport Coaches Regarding Sport Volume Recommendations and Sport Specialization. J Strength Cond Res. Epub Ahead of Print. doi: 10.1519/JSC.0000000000002529

117. Macnamara BN, Hambrick DZ, Oswald FL. Deliberate Practice and Performance in Music, Games, Sports, Education, and Professions: A Meta-Analysis. Psychological Science. 2014;25(8):1608-1618. doi:10.1177/0956797614535810

118. Macnamara BN, Moreau D, Hambrick DZ. The Relationship Between Deliberate Practice and Performance in Sports: A Meta-Analysis. Perspectives on Psychological Science. 2016;11(3):333-350. doi:10.1177/1745691616635591 


\section{APPENDIX A: ADDITIONAL RESULTS}

Table A1

Sport Specialization Classification

\begin{tabular}{cccc}
\hline Descriptive & Category & Frequency & Percent (\%) \\
\hline $\begin{array}{c}\text { Classification of Sport } \\
\text { Specialization Based off } \\
\text { Student Answers (n=56) }\end{array}$ & Low & 11 & 19.3 \\
& Moderate & 12 & 32.1 \\
& High & 27 & 47.4 \\
Classification of Sport & Low & 15 & 26.3 \\
Specialization Based of Parent & & & \\
Answers (n=56) & Moderate & 22 & 39.3 \\
& High & 19 & 33.9 \\
\hline
\end{tabular}

Table A2

Correlation Analyses $\left(r_{s}\right)$

Classification of sport specialization based off parent answers

\begin{tabular}{lc} 
Better chance to receive a scholarship or & $0.50(\mathrm{p}=0.006)^{*}$ \\
$\quad$ contract & $0.36(\mathrm{p}=0.57)$ \\
$\begin{array}{l}\text { Better chance to make the varsity team } \\
\text { Need to stay competitive with other } \\
\text { children }\end{array}$ & $0.64(\mathrm{p}=<0.01)^{*}$ \\
Improved development of Sports skills & $0.26(\mathrm{p}=0.18)$ \\
\hline
\end{tabular}

Note. *Statistically significant 


\section{Table A3}

Crosstabluation: Specialization classification based on parent responses * Do you think early sport specialization is a problem in youth sports

\begin{tabular}{cccc}
\hline $\begin{array}{c}\text { Classification of sport } \\
\text { specialization based off } \\
\text { parent answers }\end{array}$ & Do you think early sport specialization is a problem \\
\hline Not a problem & No opinion & A problem \\
Low specialization & 2 & 6 & 7 \\
Moderate specialization & 3 & 11 & 8 \\
High specialization & 8 & 3 & 8 \\
\hline
\end{tabular}

Table A4

Crosstabulation: Specialization classification based on parent answers * Rate your agreement with the following: specializing in one sport increases my child's risk of sustaining an overuse injury

\begin{tabular}{cccc}
\hline $\begin{array}{c}\text { Classification of sport } \\
\text { specialization based off } \\
\text { parent answers }\end{array}$ & $\begin{array}{c}\text { Rate your agreement with the following: specializing in one } \\
\text { sport increases my child's risk of sustaining an overuse injury }\end{array}$ \\
\hline Low Specialization & Disagree & No Opinion & Agree \\
Moderate Specialization & 1 & 5 & 10 \\
High Specialization & 0 & 9 & 12 \\
\hline
\end{tabular}


Table A5

Ordinal Regression Analysis

\begin{tabular}{|c|c|c|c|c|}
\hline Parental Belief & $\begin{array}{l}\text { Model Fitting } \\
\text { Information }\end{array}$ & $\begin{array}{l}\text { Goodness of Fit } \\
\text { (Pearson) }\end{array}$ & $\begin{array}{c}\text { Pseudo } \mathrm{R}^{2} \\
\text { (Nagelkerke) }\end{array}$ & $\begin{array}{c}\text { Test of Parallel } \\
\text { lines }\end{array}$ \\
\hline $\begin{array}{l}\text { Do you think } \\
\text { early sport } \\
\text { specialization is } \\
\text { a problem? }\end{array}$ & $\begin{array}{c}\chi^{2}=5.5504 \\
\mathrm{df}=1, p=0.06\end{array}$ & $\begin{array}{c}\chi^{2}=2.73, \mathrm{df}=2, \\
p=0.25\end{array}$ & $\mathrm{R}^{2}=0.106$ & $\begin{array}{c}\chi^{2}=2.71, \mathrm{df}=2, \\
p=0.25\end{array}$ \\
\hline $\begin{array}{l}\text { Rate your } \\
\text { agreement with } \\
\text { the following } \\
\text { statement... }\end{array}$ & $\begin{array}{c}\chi^{2}=0.68, \mathrm{df}=1, \\
p=0.71\end{array}$ & $\begin{array}{c}\chi^{2}=1.58, \mathrm{df}=2, \\
p=0.45\end{array}$ & $\mathrm{R}^{2}=0.01$ & $\begin{array}{c}\chi^{2}=1.91, \mathrm{df}=2, \\
p=0.38\end{array}$ \\
\hline
\end{tabular}

Note. ${ }^{*}$ Statistically significant 
Table A6

Odds Ratios Based off Ordinal Regression

\begin{tabular}{ccc}
\hline Comparison & Classification & Odds Ratio (95\% CI) \\
\hline No opinion : Disagree & Moderate & $0.66(0.01-33)$ \\
No opinion : Agree & High & $0.66(0.01-28.1)$ \\
& Moderate & \\
Agree : Disagree & High & $0.65(0.24-0.91)^{*}$ \\
& Moderate & $0.66(0.24-1.77)$ \\
No opinion : Not a problem & High & $1.0(0.02-43.5)$ \\
& Moderate & $1.0(0.02-39.16)$ \\
No opinion : A problem & High & $4.9(1.2-22.16)^{*}$ \\
& Moderate & $4.9(1.3-12.2)^{*}$ \\
& High & $1.5(0.51-4.9)$ \\
Problem : Not a problem & Moderate & $1.5(0.51-4.7)$ \\
& High & $3.22(0.87-13.9)$ \\
& & $3.22(0.73-31.1)$ \\
\hline
\end{tabular}

Note. ${ }^{*}$ Statistically Significant 


\section{Illinois State University \\ College of Applied Science and Technology - School of Kinesiology and Recreation - Athletic Training Education}

You are being asked to complete this form because you have agreed to take part in our research study.

The form asks questions regarding: 1) information about you [your sex, income, educational level], 2) information about your child [their sex, age, and sport participation patterns], and 3) your knowledge, attitudes, and beliefs regarding youth sports and sport specialization.

For the questions regarding your child, please answer for the child participating in today's event. If you have multiple children participating in today's event, please answer for the child who is more interested or active in sports.

Do not write your name, home address, phone number or e-mail on this form. At the top of each page, please put a unique 6-digit number that will be the same number for both you and your child.

If any of the questions make you uncomfortable, you may skip those questions.

The survey should take 10-15 minutes to complete. After you complete the survey, please turn it in to our research staff. 


\section{SECTION 1A This section is designed to help understand terms used within the questionnaire}

Below is a list of terms that the following questionnaire may use. Please refer back here if you need a more detailed explanation of the term other than the definition provided within the question.

Injury - Damage to the musculoskeletal tissues of the body resulting in the absence of the athlete in at least two athlete exposures (practice or game) following the injury incident and required the attention of a healthcare professional (i.e. Physician, Athletic Trainer, Emergency Medical Technician).

Acute Injury - Sudden and unexpected movement resulting in immediate pain and dysfunction requiring the athlete to come out of the game for any period of time. Examples include but are not limited to: lateral ankle sprain, knee sprain, any fracture.

Overuse Injury - Gradual onset of damage to musculoskeletal tissues resulting in prolonged pain and dysfunction. Examples include but are not limited to: medial tibial stress syndrome (shin splints), IT Band friction syndrome, Os good schlatters, any tendinitis/tendinopathy.

Non-Contact Acute Injury - An injury to the body whereby the individual performed a sudden or unexpected movement (i.e. rolling of the ankle, twisting of the knee) that resulted in immediate inability to play due to pain or dysfunction.

Contact Acute Injury - An injury to the body whereby the individual interacted with an external object (i.e. opposing player's body or body segment, ball, net, goal post etc.) that produced a force on the injured individual's body that may have put their body segment into a maligned position.

Organized Sport Activity - Structured events (i.e. practice or games) supervised and lead by a designated adult such as a coach or parent volunteer.

Unorganized Sport Activity - Informal play with friends or other classmates without the presence of coaches or referees. Examples include but are not limited to: playing on the street, playing sports in gym class, pick-up games/practices.

Competition - any toumament, conference, or non-conference match that was played during your primary's sport season(s).

Injury Prevention Program - A program designed to enhance the strength, balance, and flexibility of an individual to reduce the likelihood of injury. These programs are specific towards injury reduction and are not labeled as strength and conditioning programs. Examples include but are not limited to: FIFA 11+ warm up protocol, Prevent Injury and Enhance Performance (PEP) Program. 


\section{SECTION IB This section is designed to gather information about you (parent).}

1. Are you? $\square$ Female $\square$ Male

2. What is your age?

3. Estimate your combined household income (including spouse/partner)?

\begin{tabular}{|c|c|c|c|}
\hline$\square$ Less than $\$ 25,000$ & $\square \$ 25,000$ to $\$ 50,000$ & $\square \$ 50,000$ to $\$ 100,000$ & $\square \$ 100,000$ to $\$ 200,00$ \\
\hline
\end{tabular}

4. What is the highest level of education you or your spouse/partner (if applicable) have completed?
$\square$ Less than High School
$\square 4$ year college degree (BABS)
$\square$ High School GED
$\square$ Graduate degree (MS, MA, MD, PhD, JD, MBA, etc)

5. How much do you spend per year on your child's sport participation for all of their sports:

a. For school-related sport expenses?

b. For non-school related sport expenses (club/travel teams, personal coaching, etc)?

6. How many children do you have?

7. How many of your children currently participate in organized sports (school team/city league/club or travel team)?

8. How many times total in the previous 12 months have you traveled outside of your state of residence for your children's organized sport competitions (for all children)?

9. How many days per week do you participate in at least 30 minutes of moderate physical activity (brisk walking, jogging, bike riding, weight-lifting)?

$$
\begin{array}{lllllll}
{ }_{1} & \square^{2} & \square 3 & \square 4 & \square & \square 6 & \square 7
\end{array}
$$

10. What organized sports did you play as a child (check all that apply)?

$\begin{array}{lllll}\square \text { Baseball } & \square \text { Baskerball } & \square \text { Cheer/Dance } & \square \text { Cross Coumty } & \square \text { Foocball } \\ \square \text { Gymnastics } & \square \text { Ice Hockey } & \square \text { Lacrosse } & \square \text { Soccer } & \square \text { Sofftball } \\ \square \text { SwimmingDiving } & \square \text { Tennis } & \square \text { Track } & \square \text { Volleyball } & \square \text { Wrestling }\end{array}$

$\square$ Other (ist)

11. What was the highest level you played organized, competitive sports (on a school or club team)?
$\square$ Pre-high school (youth leagues)
$\square$ College
$\square$ Professional
$\square$ High School
$\square$ Semi-professional
$\square$ Master's Level 
SECTION 2 This section is designed to gather information about your knowledge and attitudes regarding youth sport participation and sport specialization.

For these questions, please answer according to the child participating in today's event.

1. How big of a concern to you is the risk of injury in youth sports?

No opinion $\quad \begin{gathered}\text { Not at all a } \\ \text { concern }\end{gathered} \quad \begin{gathered}\text { A small } \\ \text { concern }\end{gathered} \quad$ A big concern

$\square \quad \square \quad \square$

2. Do you think early sport specialization (playing one sport exclusively year round) is a problem in youth sports?

$\begin{array}{llll}\text { No Opinion } & \begin{array}{l}\text { Not a } \\ \text { problem }\end{array} & \text { A Small } & \text { A serious } \\ \text { Problem } & \text { problem }\end{array}$

$\square \quad \square \quad \square \quad \square$

3. Rate your agreement with the following statement: Participating in year-round organized sport activities increases the chances of my child sustaining an overuse injury.

$\begin{gathered}\text { Strongly Disagree } \\ \text { disagree }\end{gathered} \quad \begin{gathered}\text { Neither agree or } \\ \text { disagree }\end{gathered} \quad$ Agree Strongly agree

disagree disagree

(1)

4. Are you aware of any recommendations for the maximum amount of months ner vear that youth athletes should be participating in grganized comnetitivesnorts in order to reduce the risk of overuse injuries?

$\square$ Yes $\square$ No

5. How many months per vear do you think is an appropriate amount for your child to participate in organized, competitive sports?

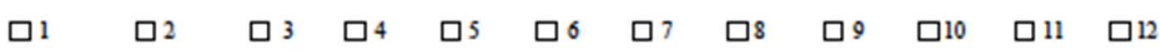

6. Are you aware of any recommendations for the maximum amount of hours ner meek that youth athletes should be participating in organized. comnetitivesports in order to reduce the risk of overuse injuries?

$\square$ Yes $\square$ No

7. How many hours ner week do you think is an appropriate amount for your child to participate in organized, competitive sports?

$\begin{array}{llllllllllllll}\square 1 & \square_{2} & \square_{3} & \square_{4} & \square_{5} & \square_{6} & \square_{7} & \square 8 & \square 9 & \square 10 & \square 11 & \square 12 & \square 13 & \square 14 \\ \square 15 & \square 16 & \square 17 & \square 18 & \square 19 & \square 20 & \square 21 & \square 22 & \square 23 & \square 24 & \square 25 & \square 26 & \square 27 & \square 28+\end{array}$

8. At what age do you believe it is best for a child to begin specializing in a single sport?

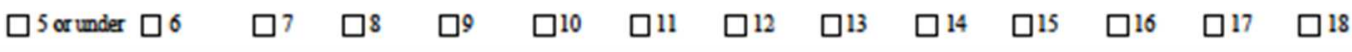


9. How likely do you believe it is that your child will receive a college scholarship that is related to athletic performance?

$\begin{array}{ccccc}\begin{array}{c}\text { Extremely } \\ \text { unilsely }\end{array} & \text { Unliksly } & \text { Neatral } & \text { Lilsly } & \text { Extremely bilsly } \\ \square & \square & \square & \square & \square\end{array}$

10. What percentage of youth athletes do you think receive a college scholarship that is related to athletic performance? (0-100\%)

11. How influential are the following factors in your or your child's decisions regarding whether your child should focus in a single sport at an early age rather than play multiple sports?

\begin{tabular}{l|l|c|c} 
Not influential & $\begin{array}{c}\text { Somewhat } \\
\text { influential }\end{array}$ & $\begin{array}{c}\text { Very } \\
\text { influential }\end{array}$ & $\begin{array}{c}\text { Ertremely } \\
\text { influential }\end{array}$
\end{tabular}

Improved development of sports slalls

Need to stay competitive with other children

Better chance to receive a scholarship/contract

$\square \square$

Better chance to malse their high school varsity team

12. How much of a concern are the following aspects of youth sports participation?

$\begin{array}{lcccc} & \text { No Opinion } & \begin{array}{c}\text { Not At All } \\ \text { a Concern }\end{array} & \begin{array}{c}\text { A Small } \\ \text { Concern }\end{array} & \begin{array}{c}\text { A Big } \\ \text { Concern }\end{array} \\ \text { Quality and Behaxior of Coaches } & & \square & \square & \square \\ \text { Time Commitment } & \square & \square & \square & \square \\ \text { Cost of Participation } & \square & \square & \square & \square \\ \text { Pressure/Behavior from other parents } & \square & \square & \square & \square \\ \text { Emphasis on vinning over having fun } & \square & \square & \square & \square \\ \text { Organizational pressure (from team organizers, coaches, administrators) } & \square & \square & \square & \square\end{array}$

13. How important do you believe the following factors of the youth sports experience are to vour child?

$\begin{array}{cccc}\begin{array}{c}\text { Not at all } \\ \text { important }\end{array} & \begin{array}{c}\text { Low } \\ \text { importance }\end{array} & \begin{array}{c}\text { Moderately } \\ \text { Important }\end{array} & \begin{array}{c}\text { Ertremely } \\ \text { Important }\end{array} \\ & & \square & \end{array}$

\section{Winning}

Spending time with friends/social interaction

Derelopment of slaills (teamwork, leadership, etc)

Having fun

Increased ability to make high school varsity teams

Getting better at their sport

Being physically active

Increased ability to play on a travel, all-star, or elite team

Increased chance of receiving an athletic college scholarship

$\begin{array}{llll}\square & \square & \square & \square \\ \square & \square & \square & \square \\ \square & \square & \square & \square \\ \square & \square & \square & \square \\ \square & \square & \square & \square \\ \square & \square & \square & \square \\ \square & \square & \square & \square \\ \square & \square & \square & \square \\ \square & \square & \square & \square\end{array}$

14. Plea se rate your agreement with the following statements:

Playing a wide-variety of sports as a child allows for better development of overall athletic ability.

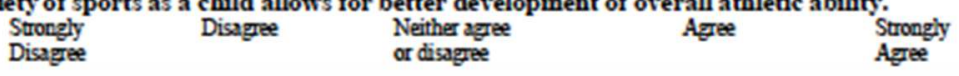

$\square \quad \square \quad \square$

$\square$ 
A child who participates in a variety of sports is more likely to be physically active as an adult.

\begin{tabular}{ll|l|l|l|l|l}
$\begin{array}{c}\text { Strongly } \\
\text { disagree }\end{array} \quad$ Disagree & $\begin{array}{c}\text { Neither agree or } \\
\text { disagree }\end{array}$ & Agree & Strongly agree
\end{tabular}

SECTION 3 This section is designed to gather information about your child and their injury history.
1. Is your child?
$\square$ Female
$\square$ Male

2. What is your child's age?

3. What grade is your child currently in at school (or what grade did they just complete)?

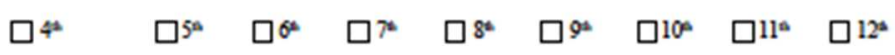

4. Does your child attend a public or private school?

$\square$ Pablic $\square$ Private

5. What organized competitive sports (school or club team) is your child participating in now OR has your child participated in within the last 12 months? (check all that apply)

$\begin{array}{lllll}\square \text { Baseball } & \square \text { Basketball } & \square \text { Cheer/Dance } & \square \text { Cross Coumtry } & \square \text { Foocball } \\ \square \text { Gymnastics } & \square \text { Ice Hockey } & \square^{\text {Lacrosse }} & \square \text { Soccer } & \square \text { Softball } \\ \square \text { Swimming/Diving } & \square \text { Tennis } & \square \text { Tack } & \square \text { Vollegball } & \square \text { Wresting }\end{array}$

$\square$ Other (ist)

6. What does your child consider their primary sport? (check one)

\begin{tabular}{|c|c|c|c|c|}
\hline$\square$ Baseball & $\square$ Basketball & $\square$ Cbeer / Dance & $\square$ Cross Country & $\square$ Foocball \\
\hline$\square$ Gymnastics & $\square$ Ice Hockey & $\square$ Lacrosse & $\square$ Soccer & $\square$ Softball \\
\hline$\square$ Swimming/Diving & $\square$ Tennis & $\square$ Track & $\square$ Volleyball & $\square$ Wrestling \\
\hline
\end{tabular}

$\square$ Other (ist)

7. What age did your child start participating in organized.comnetitire sports? (check one)
$\square 5$ a m under $\square 6 \quad \square 7 \quad \square 8$
$\square 9$
$\square 10 \quad \square 11$
$\square 12 \quad \square 13$

14
$\square 15 \quad \square 16 \quad \square 17 \quad \square 18$

8. What age did your child start participating in their primary sport? (check one)
$\square 5$ ar under $\square^{6}$
$\square^{7} \quad \square^{8} \quad \square^{9}$
$\square 10$
$\square 11 \quad \square 12$
$\square 13 \quad \square 14$
$\square^{15} \quad \square^{16} \quad \square^{17} \quad \square^{18}$

9. Please selectall months that your child participated in their primarr sport during the previous 12 months.
$\square$ January
$\square$ February
$\square$ March
$\square$ Apnl
$\square$ May
$\square$ June
$\square$ July
$\square$ August
$\square$ September $\square$ October
$\square$ Noxiember
$\square$ December 
10. Please selest all the months that your child participated in anv organized sports, including their primarr sport. during the previous 12 months.
$\square$ Janury
$\square$ February
$\square$ March
口April
$\square \mathrm{My}$
$\square$ June
$\square$ July
$\square$ August
$\square$ September
$\square$ October
$\square$ Norember
$\square$ December

11. On average, how many hours each reek does your child spend participating (practice and/or competition) in their primarr sport during that sport's season? (check one)
$\square 1 \quad \square_{2} \quad \square 3$
$\square^{4} \quad \square$
$\square 6 \quad \square 7$
$\square 8 \quad \square 9 \quad \square 10$
$\square 11 \quad \square 12 \quad \square 13$
$\square 14$
$\square 15 \quad \square$
$\square^{17} \quad \square^{18}$
$\square^{20} \square$
$\square 22 \quad \square 23 \quad \square 24 \quad \square 25 \quad \square 26 \quad \square 27 \quad \square 28+$

12. On average, how many hours each week does your child spend participating (practice and/or competition) in organized sports in total including their primarr sport? (checkene)
$\begin{array}{llllll}\square_{1} & \square_{2} & \square^{3} & \square_{4} & \square_{5} & \square_{6}\end{array}$
$\square^{15} \quad \square^{16} \quad \square^{17} \quad \square 18 \quad \square 19 \quad \square^{20} \quad \square^{21}$
$\square 22 \quad \square 23$
$\square^{24} \quad \square^{25} \quad \square^{26} \quad \square^{27} \quad \square^{28+}$

$8 \quad \square 9$

$\square 9 \quad \square$

10

13. On average, how many hours each week does your child spend participating in unorganized sport activities (playing sports with friends outside of school, playing sports in gym class, etc)? (check one)
$\square$ obours
$\square 1$ hour
口 2 bours
$\square 3$ hours
$\square 4$ hours
$\square 5$ bours
$\square$ bours
$\square 7$ bours
$\square 8$ bours
$\square 9$ hours
15 hars
$\square 11$ hours
$\square 12$ hours
$\square 13$ bours
$\square 14$ bours
$\square 15$ hours
$\square 16$ hours
口 17 hours
$\square 18$ bours
$\square 19$ or more hours

14. Does your child play their primary sport in an organized league or club outside of school?
$\square$ YES
$\square$ No

15. Does your child train more than $\mathbf{7 5}$ percent of the time in their primary sport?
$\square$ YES
$\square$ NO

16. Does your child train to improve skill and miss time with their friends as a result?
$\square$ YES
$\square$ No

17. Has your child quit other sports to focus on one sport?
$\square$ YES
$\square$ No

18. Does your child consider their primary sport more important than the other sports they play?
$\square$ YES
$\square$ NO

19. Does your child regularly travel out of state for their primary sport?
$\square$ YES
$\square$ No

20. Does your child train more than eight months a year in their primary sport?
$\square$ YES
$\square$ No 
21. For the purposes of this study, an iniurr is defined as damage to a muscle, ligament, tendon, nerre, or other soft tissue structure that caused the student-athlete to miss at least 2 consecutive days of athletic exposure (i.e. two consecutive days of practice, a day of practice and then a consecutive game day, or vice versa) and required the attention of a healthcare professional (i.e. Physician, Athletic Trainer). Considering this definition, has your child sustained an injury playing sports within the last 12 months?
$\square$ YES
口No

22. What part of the body has your child injured playing sports within the last 12 months? (select all that apply)

$\begin{array}{lll}\square \text { Hesd } & \square \text { Shoulder } & \square \text { other } \\ \square \text { Ellow } & \square \text { Wrist } & \square \text { My child has not been injured within the last } 12 \text { mocths } \\ \square \text { HnndFinger } & \square \text { Thorax } & \\ \square \text { Back } & \square \text { Hip } & \\ \square \text { Thigh } & \square \text { Knee } & \\ \square \text { Ankle } & \square \text { Foot/toe }\end{array}$

23. Of the body parts your child has injured during the last 12 months, how did the doctor, surgeon, chiropractor, physical therapist, or athletic trainer label their injury? (select all that apply)

HeadNeck

$\square$ Concussion $\square$ Contusion

$\square$ Muscle Strain $\square$ Fracture

$\begin{array}{ll}\text { Elbow } & \\ \square^{\text {Bursitis }} & \square \text { Contusion } \\ \square_{\text {Muscle Strin }} & \square \text { Fracture } \\ \square \text { Dislocation } & \square \text { Ligment Sprain }\end{array}$

HandFinger

$\begin{array}{ll}\square \text { Fracture } & \square \text { Ligament sprain } \\ \square \text { Tendocitis } & \square \text { Dislocation }\end{array}$

Back

$\square$ Low Back Pain $\square$ Heminted Disc

$\square$ Muscle Strain $\square$ Facet Joint Dysfunction

$\square$ Fracture $\square$ Nerve Root Compression

$\square$ Ligment Sprain $\square$ SI Joint Dysfunction

\section{Knee}

$\square$ Fracture

$\square$ Muscle Strain

Ligament Sprain (era

Thononists

Bursitis

$\square$ Connusion

Footitoe

Stress fracture QLignment sprain

$\square$ Nerve injury $\square$ Muscle tendon strain

$\square$ Contusion $\square$ Tendonitis

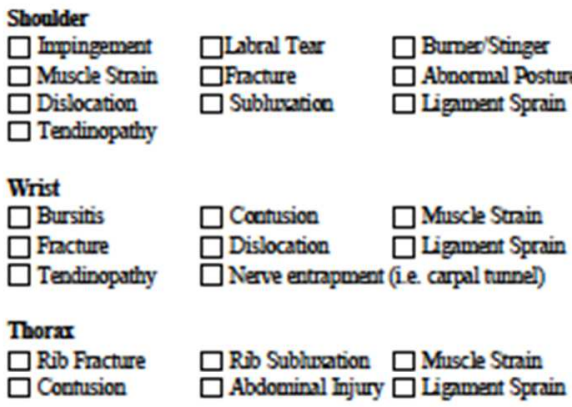

HiprThigh

$\square$ Coatusion $\quad \square$ Femoroacetabulur Impingement (FAI)

$\square$ Muscle Strain $\square$ Ligament Sprain $\square$ Tendonitis/Tendinopathy

Bursitis $\square$ Intemal Snxpping Hip Syndrome

$\square$ Extemal Suxping Hip Syndrome $\square$ Ir Bund Friction Syndrome

Lower leg anlie

$\square$ Fracture $\square$ Stress Reaction $\square$ Muscle Serain

$\square$ Tendinopathy $\square$ Medial Tibial Stress Syndrome (Shin Splints)

$\square$ Ligament Sprain $\square$ Bursitis $\square$ Nerve entrapment (ie. tarsol tunnel)

$\square$ Severs Disease $\square$ Stress Fracture $\square$ Acute Compartment Syndrome

$\square$ Evercise-Induced (Chronic) Compartment Syndrome $\quad \square$ Contusion 
24. Of the Injuries above, how many were considered overuse iniuries (gradually came about over time)? (check one)

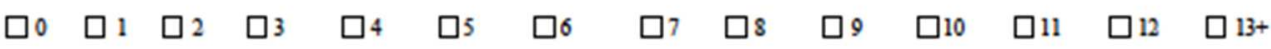

25. Of the injuries above, how many were considered acute iniuries (happened all of a sudden)? (check one)

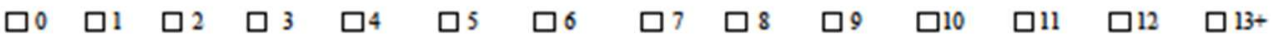

26. Of the injuries above, how many were acutecontact iniuries (involvement of another player or object)? (check one)
$\square 0 \quad \square_{1} \quad \square_{2} \quad \square$
$\square 4 \quad \square 5$
$\square 6 \quad \square$
$\square 7 \quad \square 8 \quad \square 9 \quad \square 10 \quad \square 11 \quad \square 12 \quad \square 13+$

27. Of the injuries above, how many were acute non-contact iniuries (no involvement of another player or object)? (check one)
$\square 0 \quad \square$
$\square 1 \square 2 \quad \square$
$\square 3 \square 4$
$\square 5 \square 6$
$\square 7 \quad \square 8$
प9 $\square 10$
$\square 11 \quad \square 12 \quad \square 13+$

28. Have any of the above injuries required surgery?

$\square$ YES $\quad \square$ NO

29. Has your child missed a sports season due to an injury sustained within the last 12 months?

$$
\square \text { YES } \square \text { No }
$$

30. If your child was given the opportunity to participate in an injury prevention program before the start of their sports season, would you support their involvement?

$\square$ YES $\quad \square$ NO 
Please use the space below to comment on any other aspects of the youth sport experience not covered in this survey or that you find important / beneficial / problematic / in need of improvement. 


\section{Illinois State University \\ College of Applied Science and Technology - School of Kinesiology and Recreation - Athletic Training Education}

You are being asked to complete this form because you have agreed to take part in our research study.

The form asks questions regarding: 1) information about you [your sex, sports you play, and sport participation questions], and 2) whether you have had an athletic injury.

Do not write your name, home address, phone number or e-mail on this form.

At the top of each page, please put a unique 6-digit number that will be the same number for both you and your parent/guardian.

If any of the questions make you uncomfortable, you may skip those questions.

The survey should take 10-15 minutes to complete. After you complete the survey, please turn it in to our research staff. 


\section{SECTION This section is designed to help understand terms used within the questionnaire}

$1 \mathrm{~A}$

Below is a list of terms that the following questionnaire may use. Please refer back here if you need a more detailed explanation of the term other than the definition provided within the question.

Injury - Damage to the musculoskeletal tissues of the body resulting in the absence of the athlete in at least two athlete exposures (practice or game) following the incident of injury and required the attention of a bealthcare professional (i.e. Physician, Athletic Trainer, Emergency Medical Technician)

Acute Injury - Sudden and unexpected movement resulting in immediate pain and dysfunction requining the athlete to come out of the game for any period of time. Examples include but are not limited to: lateral ankle sprain, knee sprain, any fracture.

Oreruse Injury - Gradual onset of damage to musculoskeletal tissues resulting in prolonged pain and dysfunction. Examples include but are not limited to: medial tibial stress syndrome (shin splints), IT Band fiction syndrome, Os good schlatters, any tendinitis/tendinopathy.

Non-Contact Acute Injury - An injury to the body whereby the individual performed a sudden or unexpected movement (i.e. rolling of the ankle, twisting of the knee) that resulted in immediate inability to play due to pain or dysfunction.

Contact Acute Injury - An injury to the body whereby the individual interacted with an external object (i.e. opposing player's body or body segment, ball, net, goal post etc.) that produced a force on the injured individual's body that may have put their body segment into a maligned position.

Organized Sport Activity - Structured events (ie. practice or games) supervised and lead by a designated adult such as a coach or parent volumteer.

Unorganized Sport Activity - Informal play with fiiends or other classmates without the presence of coaches or referees. Examples include but are not limited to: playing on the street, playing sports in gym class, pick-up games/practices.

Competition - any toumament, conference, or non-conference match that was played during your primary's sport season(s).

Active Recovery - physical activity or cross-training at low to moderate intensity with the intent of increasing blood flow to muscles to improve tissue repair from recent strenuous activity. Rest is not synonymous with active recovery. Examples include but are not limited to: stretching, foam rolling, yoga, bike riding, walking, swimming.

Mobility - proactive approach to enhance the recovery of muscles by addressing soft tissue restrictions, range of motion limitations, or neural tension.

Injury Prevention Program - A program designed to enhance the strength, balance, and flexability of an individual to reduce the likelihood of injury. These programs are specific towards injury recluction and are not labeled as strength and conditioning programs. Examples include but are not limited to: FIFA 11+ warm up protocol, Prevent Injury and Enhance Performance (PEP) Program 


\section{SECTION This section is designed to gather information about you (student).}

IB

1. What gender are you?

$$
\text { Male } \square \quad \text { Female }
$$

2. What is your age?

3. What grade are you currently in at school?

$$
\square 4^{*} \quad \square 5^{*} \quad \square 6^{*} \quad \square 7 \quad \square 8^{\circ} \quad 9^{\circ} \quad \square 10^{\circ} \quad \square 11^{2} \quad \square 12^{\circ}
$$

4. Do you consider yourself a single or multisport athlete? (check one)

$$
\square \text { Single } \quad \square \text { Multi }
$$

5. If you are in high school, approximately how many students attend your high school?
$\square<250$
$\square 250-499$
$\square 500-999$
$\square 1000-1499$
$\square 1500-1999$
$\square>2000$
$\square$ Nox in high schooldon't thow

5. What competitive sports (school or club team) are you participating in now OR have you participated in within the last 12 months? (check all that apply)

$\begin{array}{lllll}\square^{\text {Baseball }} & \square^{\text {Basketball }} & \square^{\text {Cheer/Dance }} & \square^{\text {Cross Coumtry }} & \square^{\text {Football }} \\ \square^{\text {Gymnastics }} & \square^{\text {Ice Hockey }} & \square^{\text {Lacrosse }} & \square^{\text {Soccer }} & \square^{\text {Softball }} \\ \square^{\text {Saimming Diting }} & \square^{\text {Tennis }} & \square^{\text {Track }} & \square^{\text {Volleyball }} & \square^{\text {Wrestling }}\end{array}$

$\square$ Other (list)

6. What do you consider your primary sport? (check one)

$\begin{array}{lllll}\square \text { Baseball } & \square \text { Basketball } & \square \text { Cheer / Dance } & \square \text { Cross Country } & \square \text { Football } \\ \square \text { Gymastics } & \square \text { Ice Hockey } & \square \text { Lacrosse } & \square \text { Soccer } & \square \text { Soffball } \\ \square \text { Swimming Diving } & \square \text { Tennis } & \square \text { Track } & \square \text { Volleyball } & \square \text { Wrestling }\end{array}$

$\square$ Other (list)

7. What age did you start participating in organized, competitive sports? (check one)

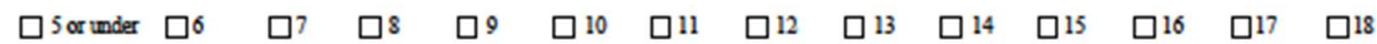

\begin{tabular}{|c|c|c|c|c|c|}
\hline$\square$ Jamuary & $\square$ February & $\square$ March & $\square$ April & $\square \mathrm{Mry}$ & $\square$ June \\
\hline$\square$ August & $\square$ September & $\square$ October & $\square$ November & $\square$ December & \\
\hline
\end{tabular}

8. What age did you start participating in your primary sport? (check one)

$$
\begin{array}{lllllllllllllll}
\square \text { or mder } & \square 6 & \square 7 & \square 8 & \square 9 & \square 10 & \square 11 & \square 12 & \square 13 & \square 14 & \square 15 & \square 16 & \square 17 & \square 18
\end{array}
$$

9. Please selectall months that you participated in vour primarr sport in during the previous 12 months. 
10. Please select all the months that you participated in anvorganized snorts including rour nrimarv sport, during the previous 12 months.
$\square$ Janury $\square$ February
$\square$ March
$\square$ Apnl
$\square$ Mry
$\square$ June
$\square$ July
$\square$ August $\square$ September
$\square$ October
$\square$ November
$\square$ December

11. On a scale of 1 to 10 , how much pressure do you feel you receive from outside sources (i.e. peers, coach, parent) to play sports? (check one)

Nopressure $\quad \square^{1} \quad \square^{2} \quad \square^{3} \quad \square^{4} \quad \square^{5} \quad \square^{6} \quad \square^{7} \quad \square^{8} \quad \square^{9} \quad \square^{10}$ Oreruheming pressure

12. On a scale of 1 to 10 , how much do you enjoy playing sports? (check one)

No enjoywent $\quad \square^{1} \quad \square^{2} \quad \square^{3} \quad \square^{4} \quad \square^{5} \quad \square^{6} \quad \square^{7} \quad \square^{8} \quad \square^{9} \quad \square^{10}$ Love playing sports

13. When you participated in your primary high school sport in its respective season during the last 12 months, how would you rate your stress levels compared to other times during the school year? (check one)

$$
\text { Lower than normal } \square \quad \text { No difference } \square \quad \text { Grester than normal } \square
$$

14. When you participated in your primary high school sport in its respective season during the last 12 months, how would you compare your sleep habits to other times during the school year? (check one)

Lower than nomal $\square \quad$ No difference $\square \quad$ Greater than normal $\square$

15. On average, how many hours each rreek do you spend participating (practice and/or competition) in wour primarr spors during that sport's season? (check one)

\begin{tabular}{|c|c|c|c|c|c|c|c|c|c|c|c|c|}
\hline ' & $\square 2$ & $\square 3$ & $\square 4$ & $\square 5$ & $\square 6$ & $\square 7$ & $\square 8$ & و & $\square 10$ & $\square 11$ & $\square 12$ & $\square^{13}$ \\
\hline$\square^{15}$ & $\square 16$ & 17 & $\square^{18}$ & $\square^{19}$ & $\square^{20}$ & $\square^{21}$ & $\square^{22}$ & $\square^{23}$ & $\square^{24}$ & $\square^{25}$ & $\square^{26}$ & $\square^{27}$ \\
\hline
\end{tabular}

16. On average, how many hours each week do you spend participating (practice and/or competition) in granized sports in total including rour primarr sport? (check one)
$\square 1 \quad \square_{2} \quad \square_{3} \quad \square$
$\square 5 \quad \square 6$
$\square 7$
$\square 8 \quad \square 9$
$\square 10 \quad \square 11$
$\square 12 \quad \square 13 \quad \square 14$

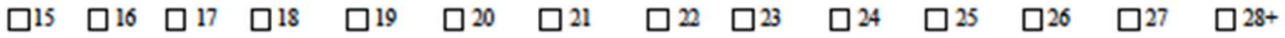

17. On average, how many hours each week do you spend participating in unorganized snort activities (playing sports with friends outside of school, playing sports in gym class, etc)? (check one)

\begin{tabular}{|c|c|c|c|c|}
\hline$\square 0$ hours & $\square 1$ hour & $\square^{2 \text { bours }}$ & $\square 3$ bours & $\square$ 4hours \\
\hline$\square 5$ hours & $\square 6$ bours & $\square 7$ bours & $\square 8$ bours & $\square 9$ bours \\
\hline$\square^{10 \text { hours }}$ & $\square^{11}$ hours & $\square^{12 \text { hours }}$ & $\square^{13}$ hours & $\square^{14 \text { hours }}$ \\
\hline$\square 15$ bours & 16 hours & $\square 17$ hours & $\square 18$ hours & $\square 19$ or more bours \\
\hline
\end{tabular}


18. For your primary sport, how many competitions did you participate in during the previous 12 months?

$$
\square 0-10 \quad \square 11-20 \quad \square 21-30 \quad \square 31-40 \quad \square 41-50 \quad \square 51-60 \quad \square 61-70 \quad \square 71-80 \quad \square 81-90 \quad \square 91-100 \quad \square 101+
$$

19. Do you play your primary sport in an organized league outside of school?

$\square$ YES $\quad \square$ NO

20. Do you train more than 75 percent of the time in your primary sport?

$\square$ YES $\square$ NO

21. Do you train to improve skill and miss time with friends as a result?

口YES $\square$ No

22. Hare you quit other sports to focus on one sport?

DYES $\square$ No

23. Do you consider your primary sport more important than the other sports?

口YES $\square$ No

24. Do you regularly travel out of state for your primary sport?

DYES $\square$ No

25. Do you train more than eight months a year in your primary sport?

口YES $\square$ NO 


\section{SECTION 2 This section is designed to gather information about your injury history.}

1. For the purposes of this study, an iniurr is defined as damage to a muscle, ligament, tendon, nerre, or other soft tissue structure that causes you to miss at least 2 consecutive days of athletic exposure (i.e. two days of practice, a practice and a game the following day, or vice versa) and required the attention of a healthcare professional (i.e. Physician, Athletic Trainer etc). Considering this definition, have you sustained an injury while playing an organized sport during the previous 12 months?
$\square$ YES
$\square$ No

2. What part of the body have you injured playing an organized sport during the previous 12 months? (select all that apply)

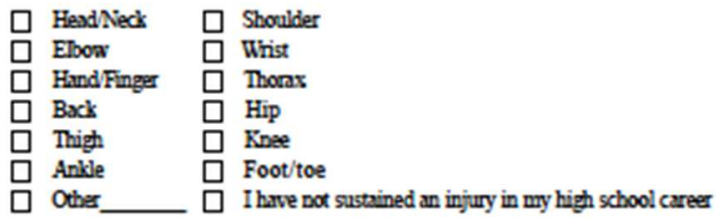

3. Of the body parts you have injured above during the last 12 months, how did the doctor, surgeon, chiropractor, physical therapist, or athletic trainer label your injury? (select all that apply)

\section{HeadNeck \\ 口 Concussion \\ $\square$ Mascle Strain $\square$ Fracture}

Elbow

$\square$ Bursitis $\square$ Contusion

$\square$ Muscle Strain $\square$ Facture

$\square$ Dislocation $\square$ Ligment Sprain

HandFinger

\begin{tabular}{ll}
\hline Fracture & $\square$ Ligment sprain \\
Tendonitis & $\square$ Dislocation
\end{tabular}

Back:

$\square$ Low Back Pain $\square$ Heminted Disc

$\square$ Muscle Serain $\square$ Facet Joint Dysfunction

$\square$ Fracture $\square$ Nerve Root Compression

$\square$ Ligament Sprain $\square$ SI Joint Dysfunction

Knee

$\square$ Fracture $\quad \square$ Ligment ppain (partial tear)

Muscle Strain $\square$ Patellofemonal pain syndrome

Ligment Sprain (grade III - full terr)

Tendinopathy $\square$ Patella dislocation

$\square$ Bursitis $\square$ Patella subluration

$\square$ Cootusion $\square$ Osgood Schlinters Disense

$\square$ Cbondromalacia $\square$ Sinding-Larson Johansson Disense

Footitoe

$\square$ Stress fracture $\square$ Ligment sprain

$\square$ Nerve injury $\square$ Muscle'tendon strain

$\square$ Contusion $\square$ Tendinoputhy
Shoulder

$\square$ Impingement

Muscle Strain

$\square$ Dislocation

$\square$ Tendinoperthy

Labral Texr

$\square$ Fracture $\square$ Abncrmal Posture

$\square$ Subluxation $\square$ Ligment Sprain

Wrist

$\square$ Bursitis $\quad \square$ Connusion $\quad \square$ Muscle Strain

$\square$ Fracture $\square$ Dislocation $\square$ Lignment Sprain

$\square$ Tendinopathy $\square$ Nerve entrapment (Lie. carpal turnel)

Thorax

$\square$ Rib Fracture $\square$ Rib Subluxation $\square$ Muscle Strain

$\square$ Connusion $\square$ Abdominal Injury $\square$ Ligoment Sprain

Hip/Thigh

$\square$ Connusion

Femoroucetabular Impingement (FAI)

$\square$ Ligment Sprain $\square$ Tendonitis/Tendinopathy

$\square$ Bursitis $\square$ Intemal Saxping Hip Syndrome

$\square$ Exdemal Snapping Hip Syndrome $\square$ IT Band Friction Syndrome

Lower leg/ andse

$\square$ Fracture $\square$ Stress Reaction $\square$ Muscle Strain

Tendinopathy $\square$ Medal Tibial Stress Syndrome (Shin Splints)

$\square$ Ligment Sprain $\square$ Bursitis $\square$ Nerve entrapment

$\square$ Severs Disease $\square$ Stress Fracture $\square$ Acute Compurtment Syndrome

$\square$ Evercise-Induced (Chronic) Coupartment Syndrome $\quad \square$ Corrasion 
4. Of the Injuries above, how many were considered oxeruse iniuries (gradually came about over time)? (check one)

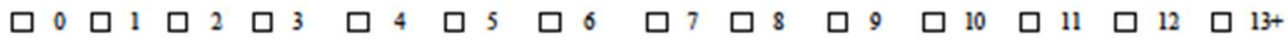

5. Of the injuries above, how many were considered acute iniuries (happened all of a sudden)? (check one)

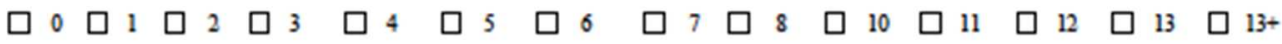

6. Of the injuries above, how many were acutecontact iniuries (involvement of another player or object? (check one)

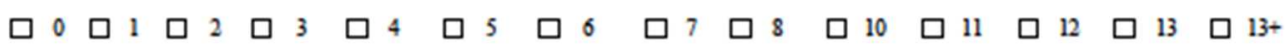

7. Of the injuries above, how many were acute non-contact iniuries (no involvement of another player or object)? (check one)

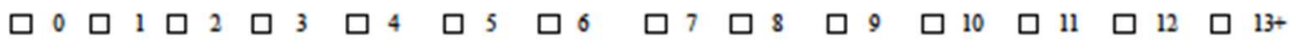

8. Have any of the above injuries required surgery?
$\square$ YES
$\square$ No

9. Hare you missed a sports season due to an injury sustained during the last 12 months?

$\square$ YES $\square$ NO

10. Which season do you consider to be your off season of your primary sport? (check one)

Fall $\square \quad$ Winter $\square \quad$ Spring $\square \quad$ Summer

I play my primary sport all 4 seasons

11. On average, how many hours do you train for your primary sport on your own during your off season? (check one)

\begin{tabular}{|c|c|c|c|c|}
\hline 0 hours $\square$ & 1 hours $\square$ & 2 hours $\square$ & 3 hours $\square$ & 4 hours $\square$ \\
\hline 6 hours $\square$ & 7 hours $\square$ & 8 hours $\square$ & 9 hours $\square$ & 10 hours $\square$ \\
\hline
\end{tabular}

12. On average, how many minutes a week do you spend performing active recorery outside of practice or games on your own with the intent of enhancing muscle repair or mobility (i.e. stretching, foam rolling, light intensity walking, light intensity biking etc.)? (check one)

$\begin{array}{lll}0 \text { minutes } \square & 10 \text { minutes } \square & 20 \text { minutes } \square \\ 40 \text { minutes } \square & 50 \text { minutes } \square & 60 \text { minutes } \square\end{array}$

13. Have you ever participated in an injury prevention program (not a synonymous with a strength and conditioning program) BEFORE a sports season?
$\square$ YES
$\square$ No

14. Would you participate in an injury prevention program before the start of a sports season if given the opportunity?
$\square$ YES
$\square$ No 